\title{
Can gene editing reduce postharvest waste and loss of fruit, vegetables, and ornamentals?
}

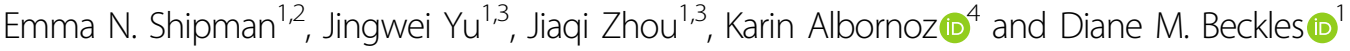

\begin{abstract}
Postharvest waste and loss of horticultural crops exacerbates the agricultural problems facing humankind and will continue to do so in the next decade. Fruits and vegetables provide us with a vast spectrum of healthful nutrients, and along with ornamentals, enrich our lives with a wide array of pleasant sensory experiences. These commodities are, however, highly perishable. Approximately 33\% of the produce that is harvested is never consumed since these products naturally have a short shelf-life, which leads to postharvest loss and waste. This loss, however, could be reduced by breeding new crops that retain desirable traits and accrue less damage over the course of long supply chains. New gene-editing tools promise the rapid and inexpensive production of new varieties of crops with enhanced traits more easily than was previously possible. Our aim in this review is to critically evaluate gene editing as a tool to modify the biological pathways that determine fruit, vegetable, and ornamental quality, especially after storage. We provide brief and accessible overviews of both the CRISPR-Cas9 method and the produce supply chain. Next, we survey the literature of the last 30 years, to catalog genes that control or regulate quality or senescence traits that are "ripe" for gene editing. Finally, we discuss barriers to implementing gene editing for postharvest, from the limitations of experimental methods to international policy. We conclude that in spite of the hurdles that remain, gene editing of produce and ornamentals will likely have a measurable impact on reducing postharvest loss and waste in the next 5-10 years.
\end{abstract}

\section{Introduction}

Plant gene editing may be the greatest innovation in plant breeding since the Green Revolution. It has already been used to make discoveries in plant biology and has a profound potential to create new crops with desirable characteristics ${ }^{1}$. There are already exciting developments, which show that gene editing may be able to live up to expectations and can be used to produce novel plant phenotypes that would improve agricultural production.

Most authorities estimate that food production will have to double in the next 50 years to keep pace with population growth $^{2}$. The focus on global food security, however, is usually on starch-rich cereals and ignores or

Correspondence: Emma N. Shipman (enshipman@ucdavis.edu) or Jingwei Yu (jwyyu@ucdavis.edu) or Jiaqi Zhou (jiqzhou@ucdavis.edu) or Karin Albornoz (karinalbornoz@udec.cl) or

Diane M. Beckles (dmbeckles@ucdavis.edu)

'Department of Plant Sciences, University of California, Davis, CA 95616, USA ${ }^{2}$ Plant Biology Graduate Group, University of California, Davis, CA 95616, USA Full list of author information is available at the end of the article underestimates the vital importance of horticultural crops. These perishable commodities are often nutrient-dense with bioactive phytochemicals, the consumption of which is needed for a healthy and thriving population ${ }^{3-6}$. However, an uncomfortable fact is that in addition to losses that may result from disease, drought, extremes of temperature, and other environmental stresses experienced in the field, an additional $25-40 \%$ - an average of 33\% - of all fruit and vegetables produced globally are never eaten after harvest ${ }^{7}$. This estimate still does not illustrate the extreme losses that can occur in some developing countries, which may be as high as $75 \%^{8,9}$. Current worldwide horticultural crop production is insufficient to meet human nutritional requirements, making postharvest loss and waste all the more unsustainable ${ }^{10}$. Only recently has the need to reduce the loss of horticultural crops after harvest been given the attention it deserves ${ }^{7-9,11-14}$.

Although the causes of postharvest loss and waste are complicated, we suggest that technology-assisted breeding 
for new and improved fruit, vegetables, and ornamentals, compatible with supply chain constraints but delivered at peak quality to the consumer, could be an important part of the solution over the long-term. In this review, we examine the potential for gene editing to make a measurable and robust impact on postharvest waste and loss. Rather than a technical or critical assessment of methodologies or research areas, we focus on connecting the bio-physiology of postharvest produce, the needs of the produce industry, and the wealth of existing molecular research, to suggest a holistic yet straightforward approach to crop improvement. The main focus of the review is the discussion of genes that could influence the quality and shelf-life of produce. First, we examine the steps that are taken to extend shelf-life in the produce supply chain, and the impact of supply chain management on consumer-desired quality traits. Then we briefly review the CRISPR-Cas9 method to emphasize the flexibility, ease, and power with which traits can be modified. Finally, we take a critical look at remaining barriers which must be overcome to make gene editing for postharvest traits technically and economically viable. This review serves both as an introduction to postharvest and gene editing and as a resource for researchers attempting to utilize the latter for the former.

\section{Overview of postharvest loss and waste (PLW)}

Postharvest waste and postharvest loss are sometimes used interchangeably, but this is incorrect. Postharvest loss is unintentional. It describes the incidental losses that result from events occurring from farm-to-table, such as physical damage, internal bruising, premature spoiling, and insect damage, among others. Produce loss is also described as quantitative because it is measurable. This does not imply that data is easily available, only that it can be assessed ${ }^{8,12}$.

Postharvest waste, in contrast, is intentional. It describes when produce is discarded because it does not meet buyer expectations, even though it is edible ${ }^{8,12}$. Produce may be rejected by growers, distributors, processing companies, retailers, and consumers for failing to meet desired or established preferences. Produce waste is described as qualitative because it is difficult to measure and assess ${ }^{8}$. Still, in the US, it is estimated that $7 \%$ of postharvest losses of fruit and vegetables occur on the farm, while more than twice that, i.e., $17 \%$ and $18 \%$ are wasted in consumer-facing businesses and in homes, respectively ${ }^{14}$.

Produce postharvest loss and waste (PLW) threatens environmental sustainability, and is especially catastrophic when viewed in the light of the twin challenges of global climate change and increasing population growth. PLW means inefficient use of financial investments in horticulture and more critically, non-renewable natural resources. Technological measures to curb PLW, such as maintaining a cold-chain and use of plastic packaging, additionally have energy and carbon costs. Improving the shelf-life and quality attributes of postharvest crops by genetic modification or smart breeding could be among many solutions to lessen the severity of these problems.

\section{The challenge of the postharvest supply web}

Produce must be kept alive from farm to table; however, the biological nature of horticultural produce is often incongruent with modern commercial supply chain operations ${ }^{15}$. Produce and ornamentals are high in water content, and often metabolically active, which makes them highly perishable ${ }^{15-17}$. This becomes a challenge given the number of food miles fruit, vegetables, and ornamentals can travel in the global supply chain (Fig. 1).

Modern postharvest supply chains may be separated spatially by thousands of miles, and temporally, by several months. Produce trucked and shipped from the field is often treated: cooled, washed, sorted, dipped, sprayed, or held at desirable temperatures and modified atmospheres to preserve "health". The majority of produce from midto large-scale operations may move through a byzantine system of processors, distributors, and trucking and shipping entities. Maintaining an unbroken cold-chain, adequate packing, and shipping are essential to preserving quality and shelf-life. (Zoom in on map to read text).

Produce, even after harvest, respires (taking up oxygen and producing carbon dioxide), transpires water, and, for the "climacteric fruits", can emit high levels of ethylene, which can be accelerated at high temperatures. Optimizing storage and handling conditions requires managing these biological processes (Fig. 2), which may differ for each produce-type or variety, and from how the preharvest environment influences biology at harvest and thereafter ${ }^{15}$. Temperature, humidity, ethylene levels, and the storage oxygen-to-carbon dioxide ratio must be controlled to slow down maturation and senescence in order to maintain produce shelf-life and quality ${ }^{15,18,19}$. Low temperatures are used to reduce respiration, thereby extending shelf-life ${ }^{18}$, but also have the added benefit of suppressing water loss, shrinkage, and fungal growth, which can occur due to physical injury and physiological disorders ${ }^{18,20}$. Modifying the atmosphere to change the carbon dioxide-to-oxygen ratio and relative humidity using modified atmosphere packaging or large-scale storage of produce in controlled atmosphere rooms can extend the postharvest life of commodities (Fig. 2).

Ethylene biosynthesis and emission underpin postharvest quality and shelf-life in climacteric fruit ${ }^{21-24}$ and vegetables $^{24-27}$. Ethylene accelerates ripening, but also senescence; therefore, ethylene must be managed to optimize shelf-life. This is underscored by the number of ethylene inhibitors, absorbers, and blockers ${ }^{18}$ on the market (Fig. 4). 


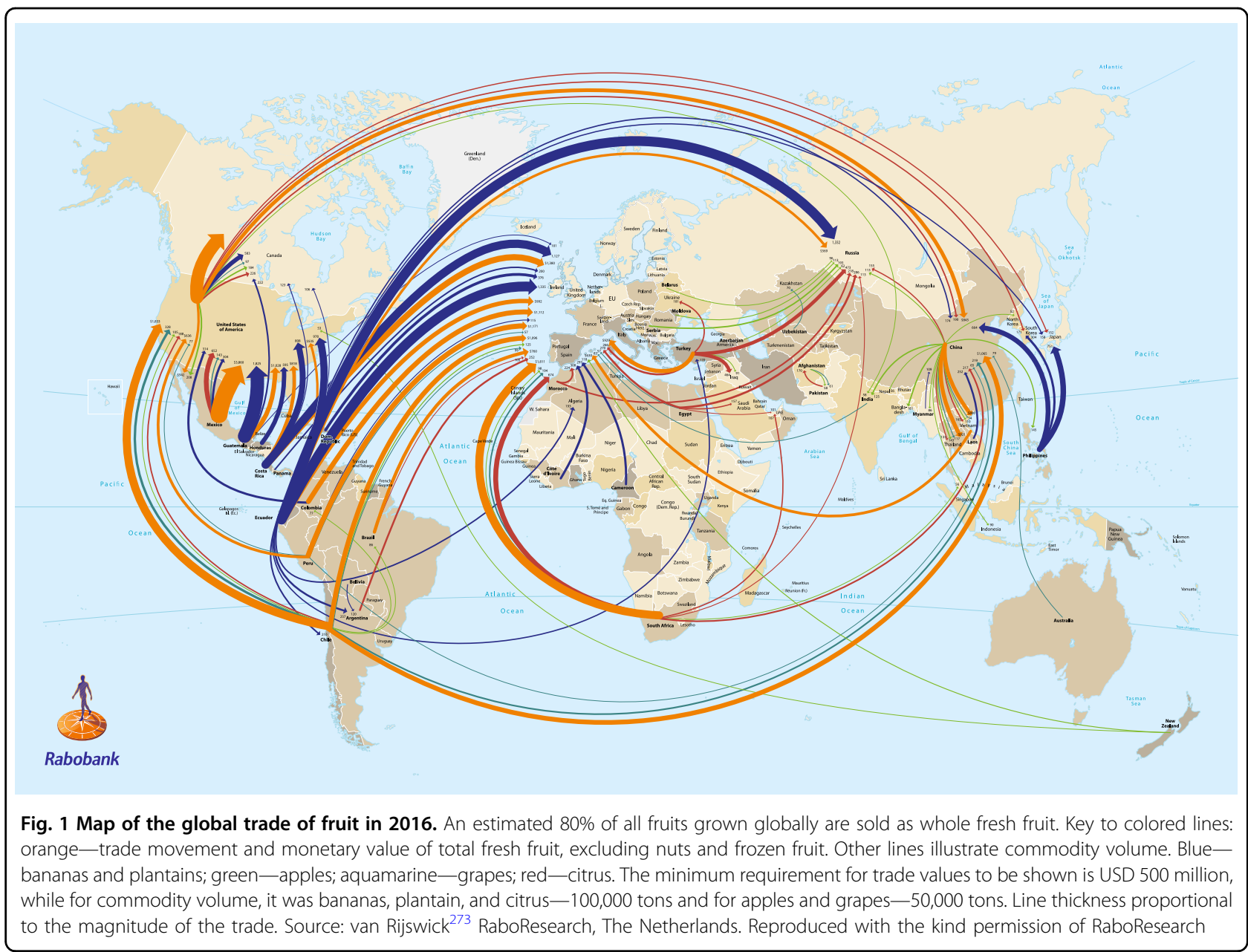

The biological reality of ripening is that its natural end is senescence. The goal of postharvest management is therefore to control this progression to senescence, i.e., to pause the ripening process for shipping and storage, and then to restart it with a minimal loss of quality. However, the processes that control the ripening-to-senescence transition dictate quality, creating a dilemma, whereby altering ripening biology via refrigeration, chemicals, or other means to lengthen shelf-life, often unavoidably disrupts ripening outcomes and reduces quality ${ }^{28}$. This leads to consumer rejection and postharvest waste. The alternative-to maximize consumer preference by harvesting produce close to peak maturity stage, and with no chemical or physical treatment, will invariably increase postharvest losses due to the shortened shelf-life, and increased susceptibility to bruising and pathogenic infection (Fig. 2).

\section{Potential for improving postharvest quality of horticultural crops by gene editing}

There is great excitement at the innovation gene editing and the associated technologies potentially bring for improving crop quality, especially for species and traits that have been relatively understudied, such as postharvest traits of horticultural crops. Manipulation of plant genomes in a precise manner has been achieved at a spellbinding pace since the era of genome editing ${ }^{29-31}$. The current gene-editing tool of choice is CRISPR-Cas9. The researcher is able to generate mutations in narrowly defined regions of the genome, and it has been successfully applied to induce valuable traits in many crop species $^{32,33}$. Further, CRISPR can bypass other burdens like sterility, self-incompatibility, high heterozygosity, low frequency of recovering desired alleles and traits and long life cycles, which extend or halt entirely conventional breeding efforts ${ }^{34-36}$.

CRISPR is a prokaryotic system that protects organisms from viral infection ${ }^{37}$. This naturally occurring mechanism in bacteria has been co-opted by scientists to remove unwanted nucleotides or to insert new or altered ones to promote traits seen as desirable in an organism of interest. For CRISPR editing, a synthetic guide RNA (gRNA) is designed to an identified protospacer adjacent motif (PAM) in the sequence of interest, and this, along with the 


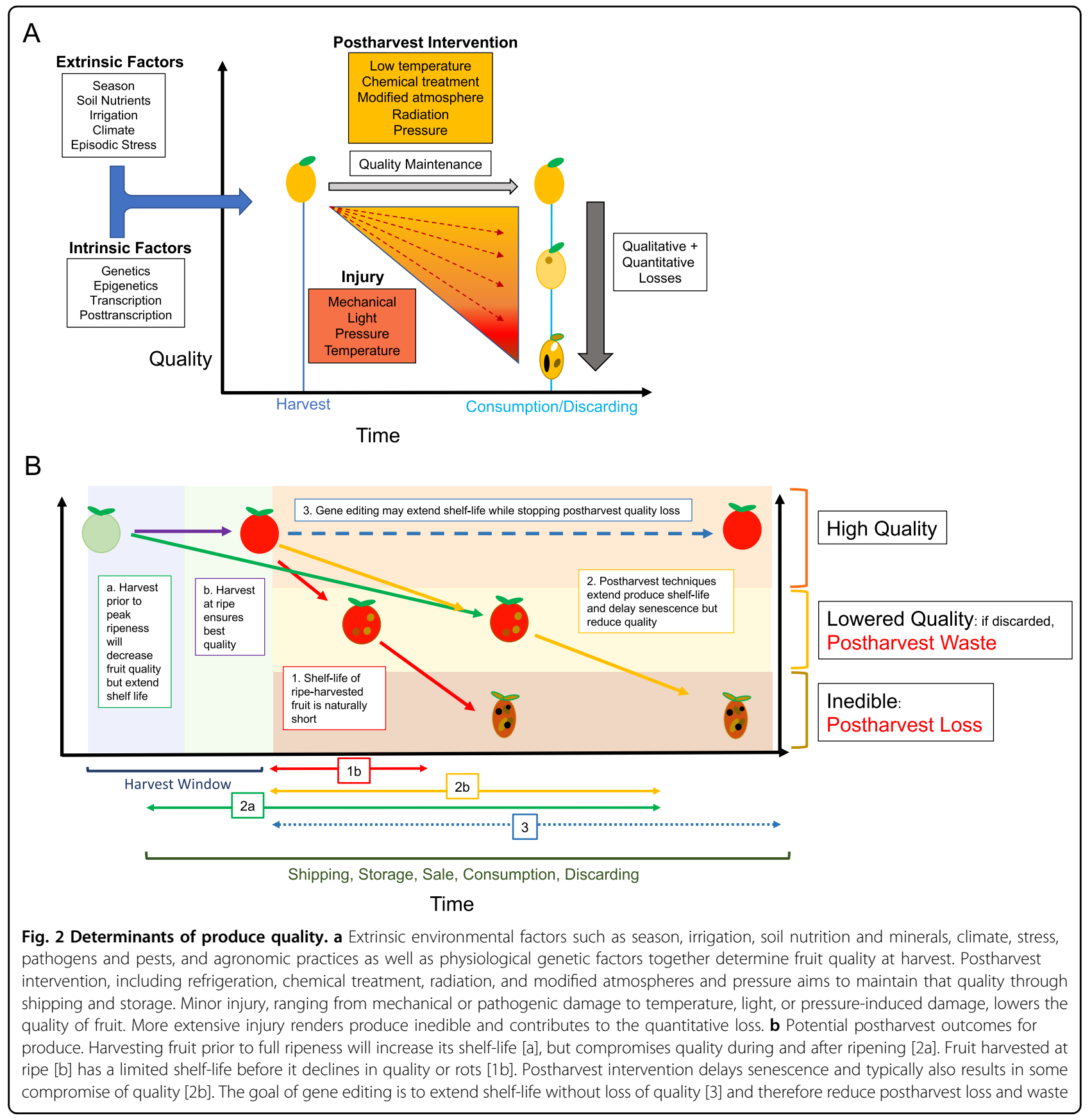

Cas protein sequence, is inserted into a cell where they are processed using the cell's gene expression apparatus. The Cas protein synthesized in the plant produces a doublestranded break (DSB) at the bases identified by the gRNA. Repair of the DSB in DNA is usually not faithful to the original sequence, and thus, non-synonymous mutations may be introduced into the genome. The precise changes in nucleotide sequences are difficult to predict, but indels (insertion-deletions) of varying sizes and singlenucleotide polymorphisms are most common, providing diverse genetic variants ${ }^{38}$. DSB repairs occur naturally in almost all plant tissues, so this is not an inherently foreign process $^{39,40}$.

Although genomic mutations generated by CRISPRmediated random repair mechanisms are easily achieved, the ability to specifically express the Cas protein in a controlled spatial-temporal manner, and in conjunction with other enzymes, is often desirable for basic and applied plant research. Precise site-directed editing can be used for single-base substitution of a gene(s) of interest ${ }^{41}$, which has been achieved in cereals ${ }^{42,43}$, as well as horticultural crops such as tomato and potato ${ }^{42,44,45}$. In addition, tissue-specific 
knockouts using a CRISPR technique, called CRISPRTSKO, can generate somatic mutations in cells, tissues, and organs by using specific promoters ${ }^{46}$. Similarly, another gene-editing system uses an inducible chimeric transcription factor (XVE), to control the expression of Cas protein in planta ${ }^{47,48}$.

Apart from knock-out/in of gene coding regions, transcriptional modulation of gene expression can be achieved by CRISPR targeting of gene regulatory elements ${ }^{49}$. New alleles generated by CRISPR/Cas in promoters and enhancers where transcription factors (TFs) bind to direct gene expression, can lead to fine-tuned expression ${ }^{1,50,51}$. Similarly, variants in upstream open reading frame (uORFs) sequences could enhance post-transcriptional modulation of gene expression, influencing phenotype ${ }^{1}$.

The expression of a gene may also be varied by changing its DNA methylation status. In tomato, orange, and bell pepper $^{52-54}$, DNA methylation regulates ripening by controlling ripening-related TFs or genes. Binding a methylation modifying protein to a CRISPR complex with a deactivated Cas $9^{55}$ may be a feasible approach to edit regions targeted for de/methylation in ripening-related genes, thus controlling shelf-life.

CRISPR-Cas also enables modulation of traits in species that are difficult to obtain through traditional breeding. Approximately $70 \%$ of angiosperms are polyploid, which increases the effort needed for introducing new alleles by crossing and selection ${ }^{56}$. Transmission of Cas activity in the progeny of CRISPR-expressing lines holds promise for transgenerational gene-editing in polyploid plants. This method was shown to introduce newly mutated alleles, not only in $F_{1}$ but also in $F_{2}$ and $F_{3}$ plants ${ }^{56,57}$. De novo domestication, a new idea in crop improvement, has been demonstrated in multiple species of the wild Solanum genus by CRISPR targeting ${ }^{58}$. Novel alleles of selected "domestication genes" are generated in wild species, landraces, or non-commercial genotypes to speed-up their transformation to elite varieties suitable for cultivation and postharvest practices of modern agriculture ${ }^{1,50,51}$.

In conclusion, various CRISPR techniques and approaches can be used to introduce nuanced changes in the expression of single or multiple genes, however, it also has real value as a tool to dissect the network of biological pathways responsible for ripening, senescence, and quality. It is expected to help identify hitherto unknown genes, that when altered, can promote favorable postharvest phenotypes. These desirable phenotypes are discussed in "Produce postharvest attributes that would minimize PLW" section.

\section{Produce postharvest attributes that would minimize PLW}

Recent consumer trends indicate a growing interest in consuming fruit and vegetables for their nutritional value.
This is especially notable for middle-class consumers of emerging economies. Gene editing to reduce PLW may improve the overall efficiency of fruit and vegetable production so that costs may be lowered ${ }^{59}$, thereby bringing fresh produce within the means of more population ${ }^{60-64}$ and strengthening the industry as well as worldwide health. There is also a demand for the produce of exceptional quality among discerning consumers ${ }^{65,66}$, a rising interest in organic and locally sourced produce, and in semi-prepared or "fresh-cut" vegetables and fruit $^{16,17,67,68}$ that are reasonably priced. Key attributes are outlined below (Fig. 3):

\section{Longer shelf-life with maximal quality retention}

Many of the approaches for extending the life of produce often lead to poor taste and flavor, and this link must be broken to increase consumer satisfaction and repeat purchases $^{68,69}$.

\section{Convenience}

The fresh-cut industry has grown over the last 20 years, driven by a demand for convenience. The ability to eat fruit and vegetables directly from the packet has been a boon to the produce industry ${ }^{70}$. Quality attributes needed to provide safe, long-lasting, visually and texturally appealing fresh-cut products can be challenging to maintain since cut produce often respires faster and is prone to browning and premature senescence ${ }^{70}$. Microbial contamination, especially of fresh-cut leafy greens and fruit by E. coli, Salmonella, and Listeria is also problematic ${ }^{71}$.

\section{Better quality}

Consumers have shown that fruit and vegetables with desirable appearance, texture, taste, and flavors will have higher salability ${ }^{16,17,65,67}$. The criteria for a favorable appearance include produce of the right color and color uniformity, correct shape and dimensions, and often a glossy surface area free from defects ${ }^{15,67,70}$ (Fig. 3). Identifying and manipulating the genes determining these pathways could improve quality. Consumers also have specific notions of what "unacceptable" produce is, and this has consequences for the generation of postharvest waste. This may vary culturally and according to socio-economic status, but general trends are identifiable. Produce with characteristics reminiscent of rotten, infested, or unripe material will be rejected. This is widely accepted as an evolutionary strategy to avoid poisoning or illness from contaminated food ${ }^{72}$, as well as a learned response based on a previous negative experience. Therefore, lesions or aromas due to age or bruising are associated with "bad" fruit and vegetables and will be rejected not only as "low quality" but as potentially dangerous, despite the produce being largely 


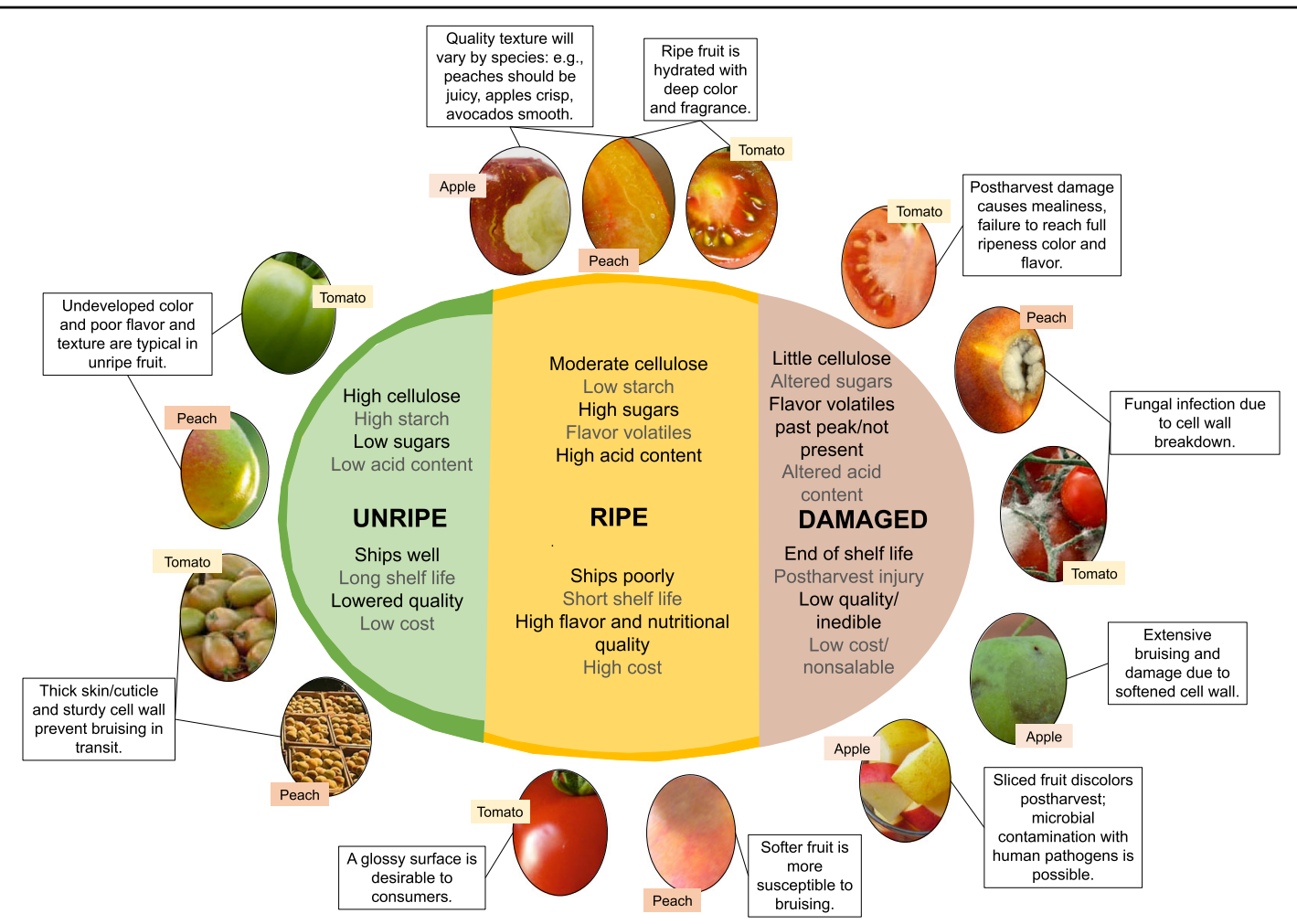

Fig. 3 Linking quality to physio-biological characteristics. The physiological factors that confer produce quality (flavor, texture, shelf-life, aroma) are determined by the amount and interactions of metabolites, both primary and specialized, present in the various tissues. Texture and shelf-life are tightly connected to the cell wall and cuticle integrity, while flavor and aroma are linked to levels of sugars, acids, and other metabolic products. Biological changes in these factors due to the natural ripening-senescence transition or, due to postharvest handling, determine consumer acceptance

intact and actually safe. While quality of flavor is widely believed to be a strong predictor of repeat purchase ${ }^{73}$, visible appearance has a strong role in initial selection or rejection at the point of purchase, and later discarding in the home $\mathrm{e}^{74,75}$. These negative traits all interact with the consumer priorities mentioned above and contribute to postharvest waste.

\section{Biological processes "ripe" for editing-shelf-life}

Although our knowledge of basic fruit and produce biology is incomplete, there has been extensive work that points to the action of individual genes which, when altered in expression, may deliver useful phenotypes. Manipulating these biological processes by gene editing is a promising new avenue for reducing PLW. Many traits, however, are determined by networks of genes, and although distinct, some networks overlap so that changes in one may have unintended consequences in another. A major challenge is to understand the complicated regulation of these pathways in order to fine-tune them in a beneficial way. Gene editing has the potential to clarify the role of individual constituents in conjunction with the production of novel varieties.

\section{Ethylene production}

As mentioned in "The challenge of the postharvest supply web" section, ethylene is a master regulator of ripening; in climacteric fruit, ethylene production must be managed to optimize shelf-life (Fig. 4), but genetic solutions may be more effective. In climacteric fruit, ethylene synthesis, regulation, and perception lead to the transcription of ripening-regulated genes that determine quality attributes desired by consumers. When $A C O$ and $A C S$ (Fig. 4) expression is genetically suppressed or silenced in a range of species, e.g., petunia, tomato, melon, papaya, and kiwifruit, ethylene production is decreased and shelf-life is extended due to slowed ripening processes ${ }^{76-83}$.

In tomato, the regulation of ethylene biosynthesis is mediated by a complex network centered around the master regulatory proteins: CNR, RIN, and NOR, which are required for normal ripening ${ }^{84}$. The recent use of CRISPR to induce targeted deletions or substitutions in $C N R^{53}$ and $N O R^{53,85}$, and in other transcription factors (Fig. 4), AP2a, FUL1, and FUL2 ${ }^{86,87}$ revealed multiple and redundant levels of regulation in the ripening pathway. Using CRISPR to create fruit varying sequentially in one or more of these transcription factors may improve our 


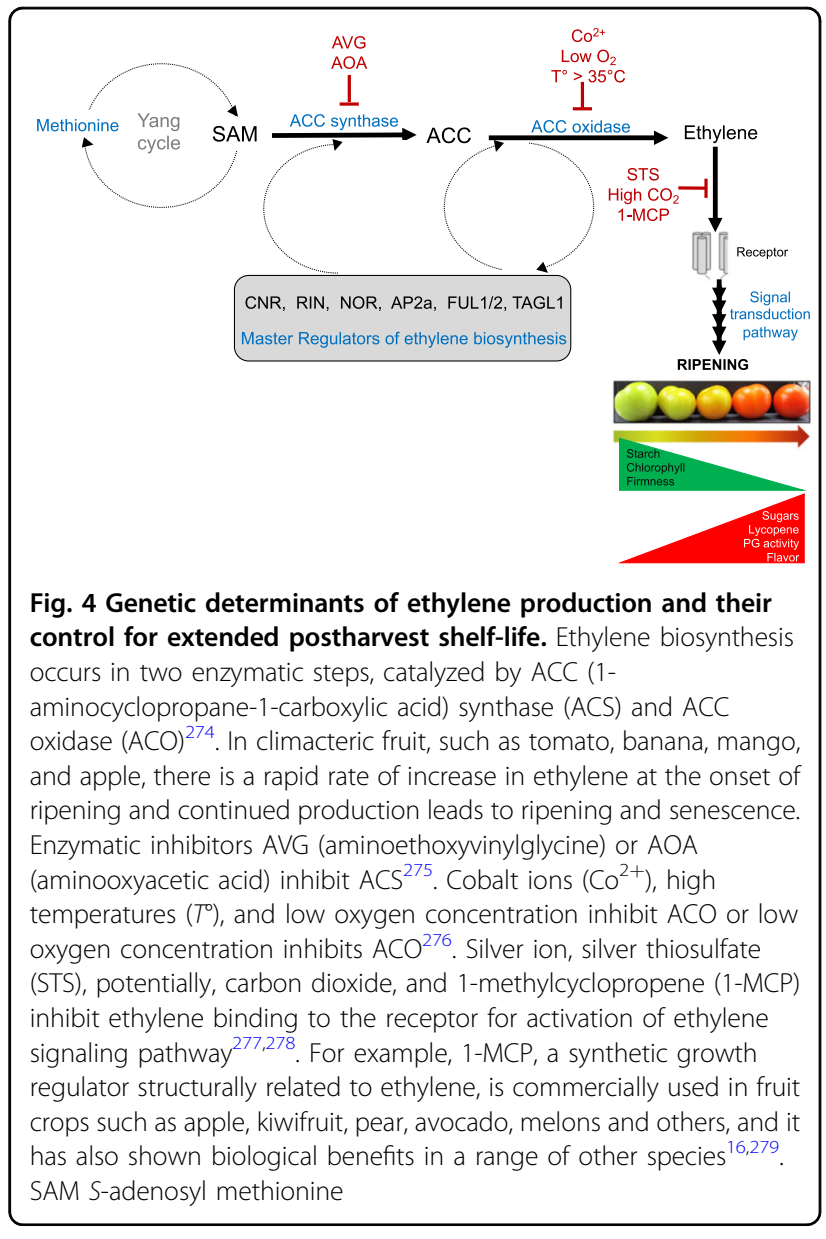

understanding of the molecular regulation of ethylene response in horticultural crops. This knowledge would allow us to control ethylene production so that ripening proceeds at the rate and with the timing that is optimal for supply chain dynamics while maintaining quality. This would directly mitigate PLW.

\section{Flower vase-life}

Global demand for fresh-cut ornamentals has increased in the past years, with an estimated value of $\$ 16 \mathrm{~B}$ in $2015^{88}$. The top producers, the Netherlands, Ecuador, Columbia, and Kenya, export floral products long distances, primarily to Europe, North America, and East Asia ${ }^{88,89}$. However, ornamental crops are highly perishable and up to $50 \%$ of the farm value may be lost along the cold-chain ${ }^{90}$, and each extra day in transit leads to a $15 \%$ loss of value ${ }^{91}$. Further, after consumer purchase, ornamental shelf-life, i.e., vaselife, is typically only $10-12$ days $^{91}$, so rapid transport along a cold-chain is essential ${ }^{91,92}$.

Ethylene has a critical role in accelerating flower senescence in some species, and targeting components of the ethylene signal transduction pathway has been successful in extending vase-life in carnation ${ }^{93-95}$ and petunia $^{54,96-98}$ (Table 1). Gene editing was also used to mutate $A C O 1$ in petunia thereby increasing flower longevity $^{99}$. In species that are not ethylene-responsive, vaselife could also be extended by inhibiting general senescence proteins $^{100}$.

\section{Fruit cuticle}

The triterpenoids and waxes coating the harvested parts of horticultural crops may have a bigger influence on quality and shelf-life than previously recognized ${ }^{101,102}$. The plant cuticle is the first layer of defense against water loss and pathogen infestation ${ }^{103}$. The cuticle is also responsible for multiple traits involved in fruit quality and shelf-life, such as surface brightness ${ }^{104}$, the characteristic "bloom" of grapes ${ }^{105}$, blueberries ${ }^{106}$ and plums ${ }^{107}$, and potentially modulating texture changes ${ }^{101}$. Fruit cuticle composition actively changes depending on the environment and organ developmental stage, which affects its protective function during fleshy fruit ripening ${ }^{108}$.

The interaction between the biomechanical properties of the fruit cuticle and cell wall polysaccharides affects the development of surface cracks in cherries ${ }^{109}$, apples ${ }^{110}$, and tomato ${ }^{111}$. These aesthetically undesirable traits for consumers can also reduce produce shelf-life. Identifying genes key to cuticle compound biosynthesis could improve fruit response to environmental stresses during postharvest storage and reduce pathogen susceptibility.

\section{Fruit softening}

The breakdown of the cell wall $(\mathrm{CW})$ during fruit ripening is a crucial process in the development of fruit sensorial quality. Softening the fruit is essential for increasing its appeal to animals and humans for consumption, and thus seed dispersal ${ }^{112}$. Ripening and senescence, together with fungal attack, accelerate the rate of CW degradation, leading to rotting ${ }^{113}$. Rotting and ripening are discussed separately, even though they overlap biologically in relation to $\mathrm{CW}$ softening and fruit shelf-life. The modern, worldwide food supply chain often necessitates that the breakdown of the cell walls, either by ripening, senescent processes or by fungal rot, be halted or slowed.

$\mathrm{CW}$ softening processes are catalyzed by multiple enzymes that respond to developmental and environmental cues and occur over a variety of timelines, depending on the organism and tissue in question. CW degradation is orchestrated by polygalacturonase (PG), pectin methylesterase (PME), pectate lyase (PL), and $\beta$-galactosidase $(\beta-G a l)^{24,114}$. PG, PME, PL, and $\beta$-Gal vary in their biotechnological potential to control firmness/fruit softening (Table 1). PG expression negatively influences firmness and shelf-life in strawberry, ${ }^{115}$ but only shelf-life in tomato ${ }^{116}$. In contrast, suppression of PLs reliably increases firmness and shelf-life in the species studied ${ }^{117-119}$. Suppression of 


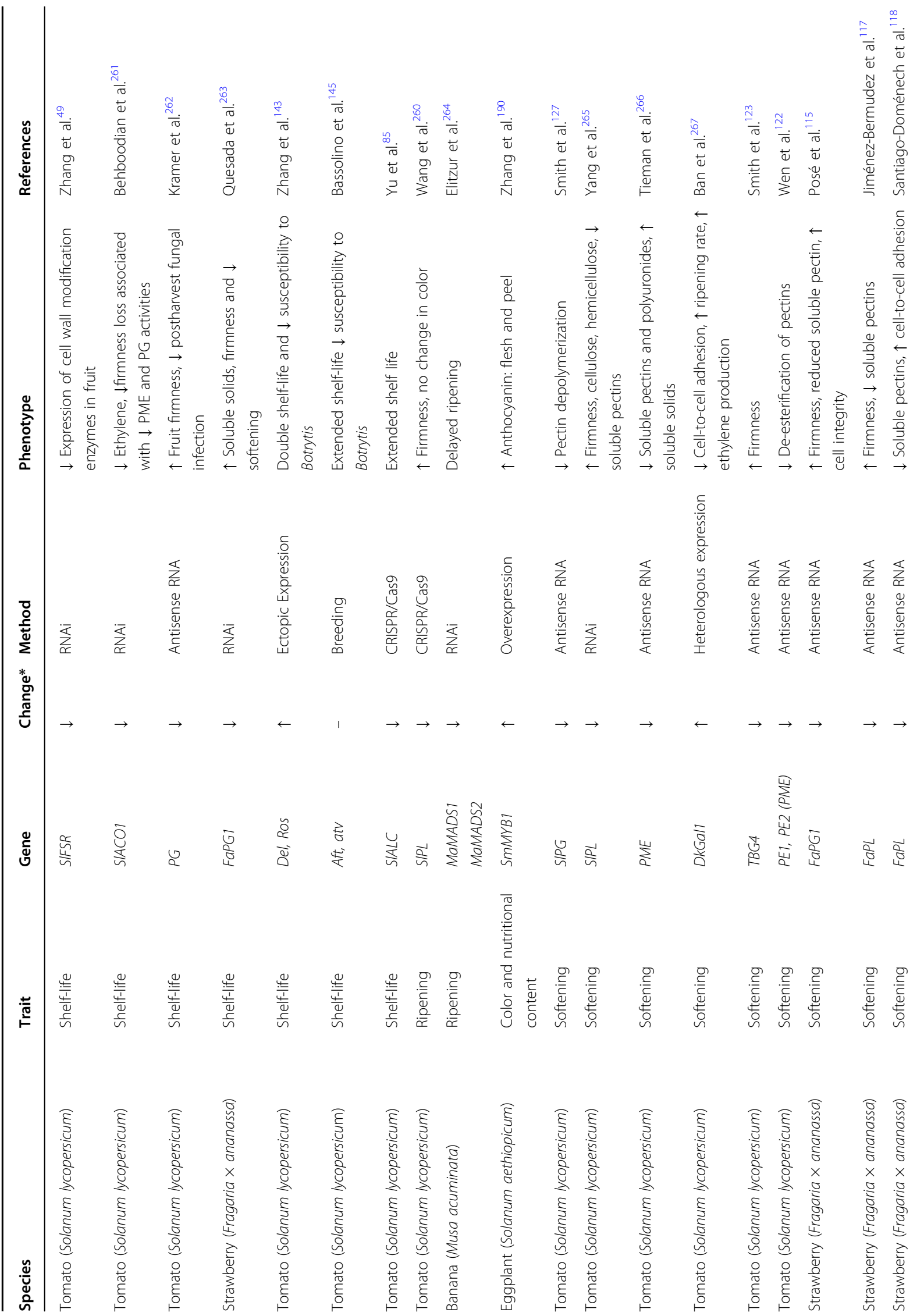




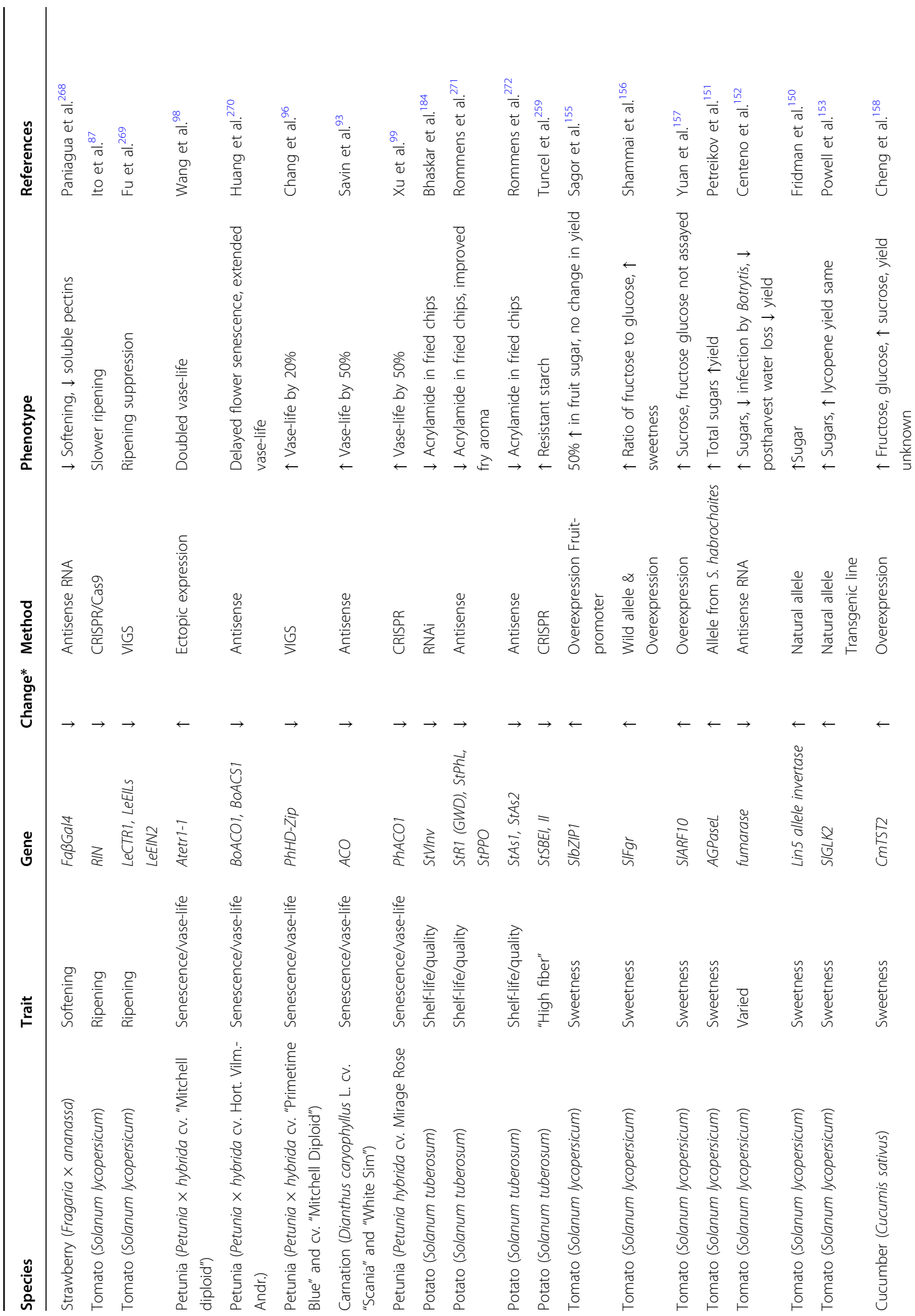




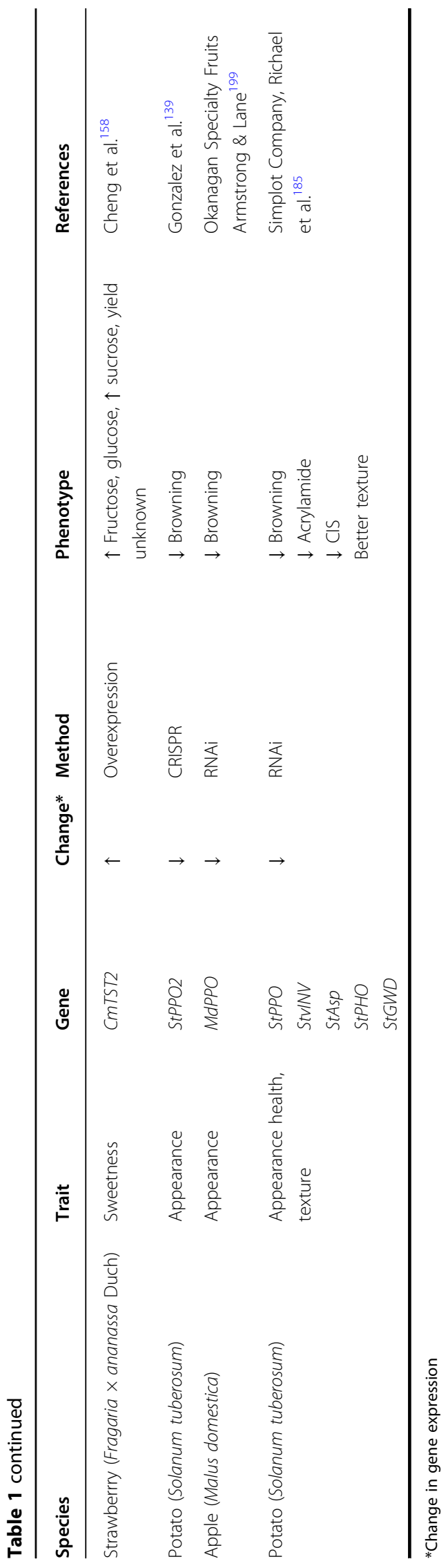

PMEs $^{81,120-122}$ and $\beta$-Gals ${ }^{24}$ promote fruit softening in many fruits. However, antisense downregulation of $\beta$-Gals in tomato caused cracking and other negative phenotypes $^{123-125}$.

Managing the timing of these CW enzyme activities could support efforts to maintain the physical integrity of fruit and vegetables from farm-to-plate. Because of the cumulative and interactive effects of these enzymes ${ }^{126,127}$, it may be necessary to intelligently target single or multiple enzymes and their inhibitor proteins ${ }^{128}$ simultaneously, to create an optimal balance of CW degradation activities. Such efforts may make it possible to surmount, bypass, or control these complex interactions, and produce fruits that retain desirable textures but that show less softening in handling, shipping, and storage.

\section{Fungal rots}

Harvested produce is susceptible to pathogenic attack. Invading fungi or bacteria will macerate the fruit components, creating rot: fruits covered in bacteria or spores, and their metabolic by-products. The result: commodities that are unsightly and also inedible due to a combination of the sour, bitter, putrid, or toxic compounds produced $^{129}$. This may be advantageous in the spreading of seeds by attracting distributing animals or physically destroying $\mathrm{CWs} \mathrm{s}^{130-132}$ but is inconvenient for postharvest storage of commodities.

Fungal infections typically occur across the physical surface: the cuticle and cell wall. Therefore, all considerations in "Fruit cuticle" and "Fruit softening" sections impact susceptibility to pathogenic attack. One approach for reducing pathogen susceptibility could be to directly target plant $\mathrm{CW}$ and ripening-related processes ${ }^{13,133}$, which would also increase shelf-life by extending the integrity of the CW. Recent work in tomato shows targeting $P L$ with gene editing may protect ripe fruit ${ }^{134}$.

Gene editing of endogenous plant enzymes that target fungal CW components and linkages could enhance resistance to fungal infection ${ }^{135-137}$. Further, the accumulation of specialized metabolites conferred pathogen resistance in several citrus species ${ }^{138,139}$ and could be a target for editing in others ${ }^{140,141}$.

\section{Composition \\ Anthocyanins}

Many of the red, blue, and purple colors seen in fruit, flowers, and tubers are due to anthocyanins. This class of compounds is not only aesthetically pleasing but has healthful antioxidant properties ${ }^{142}$. In addition, highanthocyanin accumulation has been linked to increased shelf-life and reduced Botrytis infection in tomato. This was shown via ectopic expression of anthocyanin biosynthesis genes from snapdragon in tomato under a fruit specific promoter ${ }^{143,144}$, as well as by introgression of 
naturally occurring $A b g$, Aft, and atv high-anthocyanin alleles into tomato ${ }^{145,146}$. Increasing anthocyanin production in tomato and other fruit, could simultaneously enhance shelf-life for reduced postharvest loss, but also reduce postharvest waste by increasing the attractiveness of the fruit due to healthful properties and novel color.

\section{Carbohydrates}

The primary carbohydrates studied are starch and sugars, and their interconversion, content, and relative amounts may influence postharvest quality. Starch breakdown to sugars is undesirable in potato (see "Coldinduced sweetening" section), but during maturation, it is valuable in several species, e.g., apple, banana, and kiwifruit. In others, e.g., sweet peas and sweet corn, the conversion of sugars to starch reduces sweetness and hence quality.

\section{Sugars}

Sweetness is an important attribute in fruits. Sweetness is determined by the concentration and relative ratio of the predominant sugars in fruit tissues ${ }^{67,69}$, although amino acids and other compounds may have an effect ${ }^{147}$. The biochemical pathways that lead to sugar accumulation have been studied, however, transgenic manipulation of these genes often has negative effects on yield $^{148}$, indicating that a more fundamental and holistic knowledge of sugar metabolism, especially its regulation, is needed ${ }^{149}$. However, high sugar Quantitative Trait Loci (QTLs) used in breeding programs ${ }^{150-152}$ and, the recent discovery of regulatory genes which influence fruit sugar accumulation ${ }^{153-158}$, are promising targets for improving fruit taste (Table 1). Gene editing for increased sugar may mitigate the loss of tissue sugar content or capacity that occurs due to postharvest handling ${ }^{69}$ and therefore maintain consumer satisfaction, reducing postharvest waste.

\section{Starch}

The starch-rich organs of cassava, yam (Dioscorea spp.), and potato are important staples, but unlike cereal grains, they are highly perishable ${ }^{159}$. There is interest in changing the digestibility of starch to create varieties with different nutritional attributes ${ }^{160}$. For example, low-digestible, i.e., "fiber-like" starch would be healthier upon consumption, and could conceivably resist breakdown in storage, reducing postharvest loss. Transgenic alteration of the starch branching enzymes in potato showed that increasing "resistant starch" could be recapitulated in a horticultural crop ${ }^{161-168}$.

Starch also accumulates in the immature fruit of apples, bananas, tomatoes, and kiwifruit ${ }^{169}$, and its breakdown to sugars at maturity makes valuable contributions to ripe fruit sugar content ${ }^{151,170}$. Increasing starch content by manipulating regulatory proteins and transporters (Table 1), has been identified as a viable strategy for increasing the postharvest quality of ripe fruit ${ }^{171,172}$.

\section{Cold-induced sweetening}

Potato tubers are stored at low temperatures $\left(4-8^{\circ} \mathrm{C}\right)$ to extend shelf-life and meet industry demand for roundthe-year fresh products. However, sucrose and reducing sugars (glucose and fructose) accumulate during cold storage from starch breakdown, a process referred to as cold-induced sweetening $(\mathrm{CIS})^{173,174}$. CIS affects the quality of fried potato products: reducing sugars react with amino acids during high temperature cooking to form carcinogenic acrylamide through the Maillard reaction ${ }^{175,176}$. Several metabolic pathways, including starch biosynthesis and degradation, are involved in $\mathrm{CIS}^{177-180}$. Reducing vacuolar invertase activity decreased reducing sugars and alleviated CIS in transgenic tubers $^{181-185}$. These genes are therefore ideal targets for manipulation using a gene-editing approach. Reducing CIS would lessen the severity of tuber postharvest starch loss and would also reduce the postharvest waste that results when blackened chips and fries are discarded.

\section{Flavor profiles}

There seems to be a consensus among consumers that store-bought fruit and vegetables often lack good flavor; one consequence of this assessment is PW. The flavor is determined by the intricate combination of sugars, acids, and volatiles ${ }^{186}$. Improving flavor is made even more challenging because "good flavor" is subjective and varies across and among different consumer populations ${ }^{187-189}$. Postharvest handling and retail systems are major contributors disrupting many of the pathways required for full fruit flavor, especially volatile production ${ }^{190}$. Painstaking efforts have been made to link the abundance of specific chemicals, especially aroma volatiles, to human likeability using sensory panels ${ }^{191,192}$. However, because of the complexity of fruit flavor profiles, targeting multiple genes that affect sweetness, acidity, and aroma is likely necessary to truly improve consumer appeal ${ }^{193}$, a challenge that gene editing may meet more readily than traditional breeding ${ }^{194}$. For example, in tomato, fructose, citric acid, and six aroma volatiles were associated with a high hedonistic value ${ }^{193}$. Novel alleles of genes that contribute to enhanced fruit flavor ${ }^{194,195}$ were related to sugar content, citrate, and volatiles, all of which may be manipulated by gene editing to develop the fruit of optimal flavor ${ }^{196}$.

\section{Reduced browning}

Many horticultural crops exhibit undesirable browning that is a turn-off for consumers who discard these edible but "downgraded" produce ${ }^{197}$. Browning is common in 
fresh-cut or bruised produce-lettuce, spinach, apples, and potatoes-or is due to physiological disorders such as heat and chilling injury, or exposure to inappropriate oxygen and carbon dioxide levels ${ }^{197}$.

There are two types of browning, enzymatic and nonenzymatic. Non-enzymatic browning describes the Maillard reaction, discussed in the "Cold-induced sweetening" section. Enzymatic browning involves the action of three core enzymes: polyphenol oxidase (PPO), peroxidase (POD), and phenylalanine ammonia lyase (PAL) ${ }^{197}$. Scientists have successfully shown that knocking out PPO genes reduced browning upon wounding. This is a relatively easy target and a proven and effective strategy for reducing postharvest waste ${ }^{198}$. Non-browning, commercially available produce i.e., Innate potato ${ }^{\circ}$ and Arctic Apple ${ }^{\circledR}(\text { Table } 1)^{185,199,200}$ are in retail outlets. Nonbrowning mushrooms have also been produced by CRISPR-Cas9 gene editing ${ }^{201}$. Manipulation of this trait is expected to make significant inroads in reducing consumer disposal of "browned" but edible produce, especially for those that are "fresh-cut."

\section{Complex postharvest traits}

There are many postharvest phenotypes that influence the quality and shelf-life of crops that are poorly understood at the molecular level. These traits may be influenced by the activity of multiple genes and their alleles, and how their expression is altered by the environment (see "Identifying genes that influence postharvest traits" section). Our understanding of the disorders that result from these combined elements, along with those discussed in "Composition" section, is hampered by the influence of preharvest factors, which are often not taken into account, and study-to-study variability in experimental design and reporting inconsistencies ${ }^{69,202}$. Postharvest disorders that affect a wide variety of species are discussed below.

\section{Microbial food safety}

Salmonella and E. coli contamination of fresh-cut fruit, vegetables, and especially leafy greens can occur at various points in production, causing illness or even death if consumed $^{71,203}$. E. coli $\mathrm{OH} 157: \mathrm{H7}$, alone has sickened 72,855 people and led to 173 deaths in the US from $1980-2016^{204}$. These outbreaks have increased in frequency due to (1) intensive farming, (2) the growing complexity of the postharvest supply web, and the (3) popularity of fresh-cut salads, which offer more entry sites for pathogen infestation ${ }^{204-206}$. The problem is that a localized outbreak of a commodity often temporarily suppresses sales and demand, leading suppliers to dump unaffected product, creating waste.

The development of breeding strategies to reduce bacterial attachment, persistence, and proliferation, have the potential to reduce food contamination ${ }^{203,207}$. Identifying genomic regions in Salmonella controlling stomatal opening in lettuce leaves ${ }^{208}$, and screening germplasm for tolerance to microbial pathogens are important steps ${ }^{209}$. This type of fundamental knowledge could open new avenues for developing genetic strategies for improved food safety ${ }^{210}$ including gene-editing strategies.

\section{Postharvest chilling injury}

Low temperatures typically extend shelf-life, but in some produce, when rewarmed after chilling, the normal maturation program is disrupted, leading to poor quality ${ }^{190}$. This physiological dysfunction called Postharvest chilling injury (PCI) is manifested in a wide array of symptoms across species, the most severe of which include tissue and seed browning or blackening, pitting, fungal infestation and decay ${ }^{20,211}$, which contribute to postharvest loss. Mild PCI symptoms include a lack of flavor, and undesirable texture and taste ${ }^{20,211}$, which leads to postharvest waste.

We estimate that $\sim 56 \%$ of the top 50 global commodities are susceptible to PCI. Further, the symptoms are often hard to specifically ascribe to chilling injury: PCIaccelerated decay is often diagnosed as postharvest disease or premature senescence ${ }^{212}$, and poor flavor induced by $\mathrm{PCI}$ is often blamed on variety-type or early-harvest. $\mathrm{PCI}$ is insidious because it is difficult to detect, and it is therefore not properly documented ${ }^{28}$. It also adds constraints to postharvest management strategies for sensitive crops, as preventing PCI requires faster shipping at higher temperatures or shorter storage times.

A new gene discovery holds promise for reducing the occurrence of PCI. The SlGRAS4 gene, when overexpressed in transgenic tomato by $\mathrm{RNAi}$, promoted postharvest chilling tolerance in fruit with no change in yield ${ }^{213}$. SlGRAS4 overexpression may also be achieved by editing repressor elements in its promoter in the future.

\section{Preharvest factors}

The metabolic and physiological state of a commodity before harvest is a key factor determining its postharvest quality. Soil elemental composition, especially nitrogen and calcium, crop exposure to extreme heat, drought, or even wind, and irregularities in irrigation regime can affect a broad array of quality parameters that may make produce unsuitable for sale (Fig. 3$)^{214,215}$. Visible blemishes such as lettuce tip burn (Fig. 5) are often linked to temperature effects ${ }^{216}$. Still, overwhelmingly, these physiological traits are some of the most difficult to dissect due to the unpredictable nature of the severity and frequency of their occurrence. Identifying genes that could be modified for improvement may be more problematic than for other traits. 


\section{Postharvest storage disorders}

Postharvest treatments are used to prolong produce shelflife (Fig. 2), but incorrect exposure or treatment can disrupt

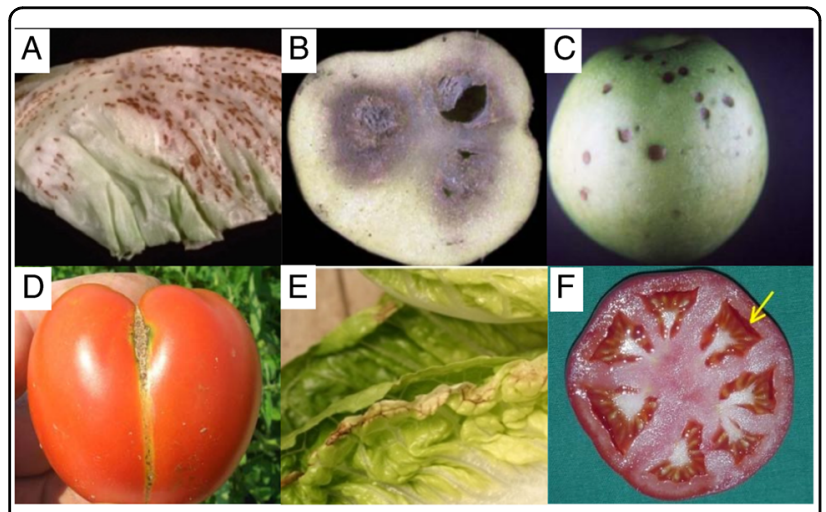

Fig. 5 Postharvest disorders in fruit and vegetables. A Russet spotting in lettuce, B blackheart in potato tuber, $\mathbf{C}$ bitterpit in apple, $\mathbf{D}$ zippering in tomato, $\mathbf{E}$ tipburn in lettuce, $\mathbf{F}$ puffiness in tomato fruit. Pictures reproduced with kind permission from UC Davis Postharvest Technology Center (A, C), Marita Cantwell (B), Gerald Brust (D), Richard Smith (E), and Elizabeth Maynard (F) metabolism, leading to physiological disorders occurring in the harvested product ${ }^{217,218}$. These injuries may be initiated at the cellular level due to the overproduction of reactive oxygen species, membrane damage, and energy imbalances caused by interferences in ATP production ${ }^{219}$.

Over time, secondary reactions occur and result in visible changes, e.g., water soaking, tissue browning, blackening, microbial growth and decay, off-flavors, and odors ${ }^{214,217,219}$. Common postharvest disorders include russet spotting in lettuce and blackheart in potato (Fig. 5). The genes underlying these phenotypes are very poorly understood, and studies are complicated because there are multiple interacting factors that result in the trait. The use of -omics technology and the mitigative effects of some hormonal or hormetic physical treatments have led to a better understanding of the signal transduction pathways affected ${ }^{219}$, but more work needs to be done to determine candidates for gene-editing solutions because these traits lead to PLW.

\section{Roadblocks impeding the broader adoption of gene editing for reducing PLW}

Commercial and public implementation of gene editing has been occasional and non-systemic. The reasons for

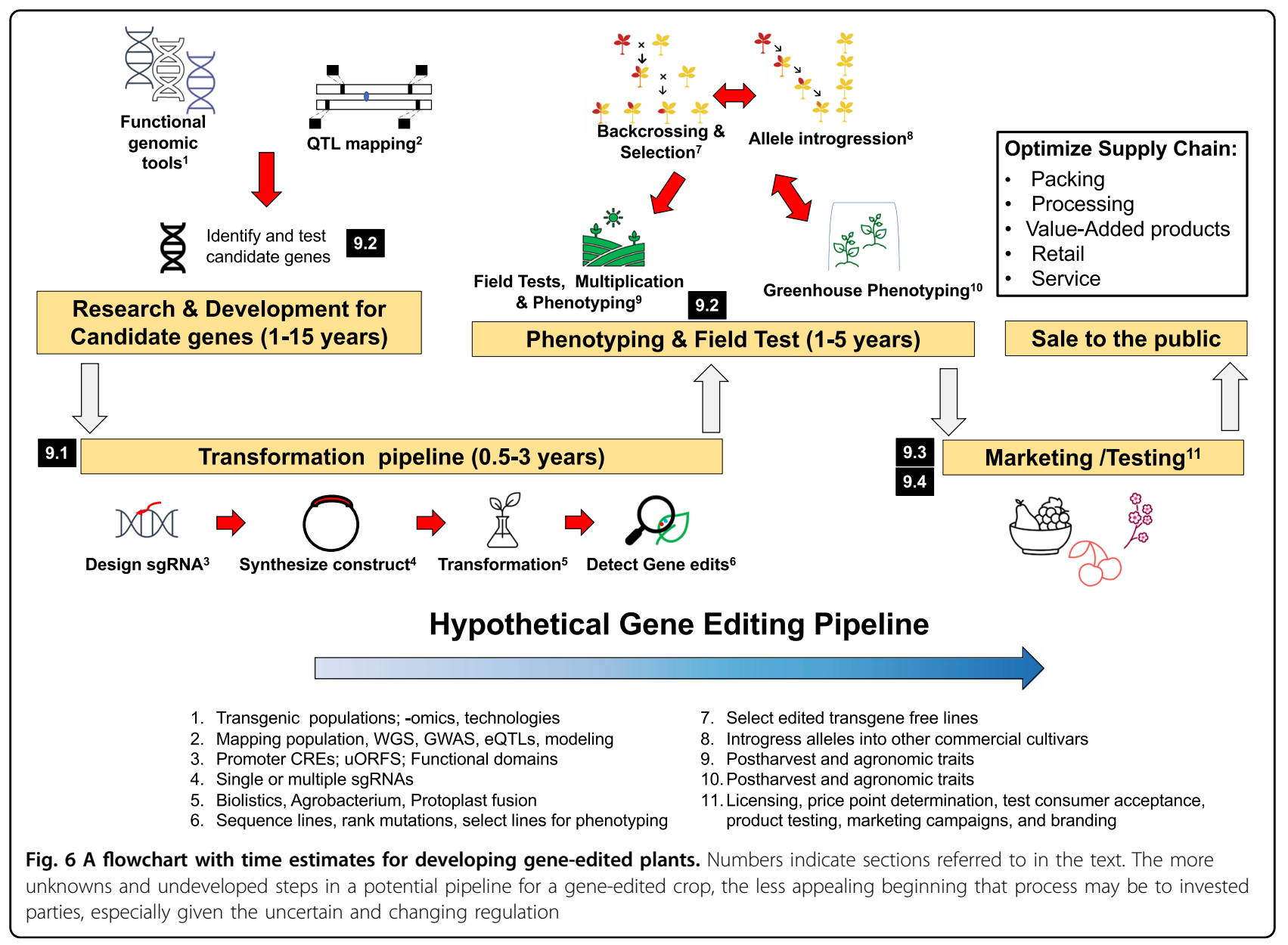


this are manifold and interconnected; however, most stem from two primary issues.

First, many horticultural crops have been traditionally understudied because their lifecycle, genomic structure, or inability to regenerate via tissue culture, are not amenable to methods used in functional genomics. This leads directly to the second reason: many of the genes that contribute to the problems of PLW have not yet been identified. These two identified stumbling blocks will require new and significant financial investments to minimize their effect and accelerate the use of gene editing for reducing PLW (Fig. 6).

\section{Plant transformation and regeneration}

Although transgenic approaches for modifying plants have been advanced for three decades, transformation and regeneration (Fig. 6) are bottlenecks in using gene-editing tools to address crop improvements ${ }^{220,221}$. The efficiency of Agrobacterium-mediated approach varies by Agrobacterium strain, and the plant species and tissue to be transformed ${ }^{183}$. Almost $95 \%$ of woody fruit and nut crops are still recalcitrant to transgenic approaches because of poor transformation efficiencies using Agrobacterium ${ }^{222}$. Transformation may be achieved using biolistic and electroporation approaches, which are non-tissue specific $^{223}$ but lead to multiple insertions which can create additional non-intended genetic changes.

Regeneration through tissue culture is even more challenging than the integration of foreign genes, and the process is time-consuming (Fig. 6). Regeneration takes 6-9 months for papaya ${ }^{224}, 5-8$ months for kiwifruit ${ }^{225}$, and 4-5 months for potato ${ }^{220,226}$. Novel delivery approaches to bypass labor-intensive plant regeneration procedures are being developed. "Spray-on" gene editing involves coating nanosized carbon dots with plasmids containing gRNA and Cas9 cDNA, which are delivered directly to the cell ${ }^{227}$. Inducing meristem formation in tissues transformed with the CRISPR gene construct would produce edited plantlets without a callus explant step, thus saving time ${ }^{228}$. Seeds produced from such plants could be propagated ${ }^{228}$. Recent innovations promise to open up the number of crops that can be efficiently modified by gene editing ${ }^{229,230}$. Specifically, transforming calli with a GRF4-GIF growth factor chimera has been used to accelerate regeneration efficiency more than 5-fold among some of the most recalcitrant species ${ }^{229}$, and may be a major advance in crop improvement.

\section{Identifying genes that influence postharvest traits}

Many postharvest traits are composite, with phenotypes that are the result of multiple environmental factors as well as genetics (Eq. 1). As mentioned, common disorders such as PCI, blossom end rot, and superficial scald, are

$$
P=f\left(G \star E_{f} \star E_{p} \star M_{p}\right)
$$

Eq. 1 Factors contributing to postharvest phenotype. Where $P=$ postharvest phenotype; $f=$ function; $G=$ genotypic factors; $E_{f}=$ field preharvest environment; $E_{\mathrm{p}}=$ postharvest environment; $M_{\mathrm{p}}=$ postharvest management. Factors are interactive and presumed to be non-additively, nonlinearly compounding: we use the star operator to suggest the dynamism of a cross-correlation function; though this concept is not typically applied to biological systems, it is evocative here.

challenging to study at the molecular level. These traits are likely to be multigenic and multiallelic, with gene expression controlled in networks involving epistatic interactions and epigenetic mechanisms, that are influenced by environmental factors ${ }^{231-237}$.

For many years, environmental control, i.e., refrigeration and modified and controlled atmospheres, was the primary way of maintaining shelf-life and quality ${ }^{15}$. Forward genetic approaches such as QTL and Association mapping, mutagenesis, and gene expression analysis, have been used to identify candidate genes that exert a significant degree of control over complex agricultural traits $^{238,239}$. However, introgressing favorable genes into a new cultivar may not always lead to the strong expression of a trait, because of environmental effects ${ }^{240}$.

\section{Patent landscape}

There is much uncertainty about the right to market edited germplasm. In the United States, the Broad Institute holds the patent for CRISPR editing of eukaryotic cells ${ }^{241}$. However, the University of California continues to challenge the 2018 ruling on multiple grounds ${ }^{242-244}$. In most of Europe and the Pacific (China, Australia, Singapore), the University of California holds the rights to CRISPR ${ }^{241}$. As shown in Fig. 1, the perishable fruit, vegetable, and ornamental market is global. Those interested in growing "CRISPR'ed" produce in, e.g., California, and selling it in the US, Canada, China, and Australia, might need to invest millions to acquire permissions from both Broad Institute and the University of California ${ }^{241}$. This may increase the entry cost to commercialize postharvest gene-edited products, and limit the traits targeted to those with the highest profit-margin and simultaneously, push out smaller, "boutique" biotechnology firms ${ }^{241}$.

The public sector has not hesitated to use CRISPR ${ }^{245-247}$. The Broad Institute allows unrestricted use of the Intellectual Property covered in its CRISPR patents for nonprofit and academic research uses, but commercial planting of the fruits of that research is open to legal challenge ${ }^{248,249}$. Currently, in the US, commercial growers frequently invest in public breeding programs by providing land for field trials to state-level institutions. Material support from for-profit entities may become legally 
tenuous if a laboratory or facility is using CRISPR or any other patented technology.

As CRISPR techniques become more refined ${ }^{246,247}$ and additional patents are submitted, these legal and financial contingencies may become more labyrinthine. However, the explosion in CRISPR research in plants, shows that the agricultural and horticultural world is eagerly embracing gene editing. The promised profit improvements currently outweigh the potential legal ramifications of patent infringements.

\section{Regulatory issues}

Another roadblock to the commercialization of geneedited horticultural crops is their differing classification across the globe. The United States and China, which produce and consume a majority of the world's fruit and vegetables (Fig. 1), have readily embraced gene editing ${ }^{240}$, and regulation in India is based largely on precedent ${ }^{250}$. Modifications produced by gene editing vs. traditional breeding can be functionally identical, and distinguishing said modifications is near impossible ${ }^{251-253}$. As a result, in June 2020 the United States announced the SECURE rule, stating that from April 2021, novel crops with DNA changes that could be introduced by traditional breeding can be fast-tracked for marketing ${ }^{254}$. The European Union, however, has ruled that gene-edited crops are in the same classification as "traditional" GMOs ${ }^{252,255,256}$. This places additional burdens on companies wishing to market edited produce in the EU and $\mathrm{UK}^{255}$. European produce markets have high quality standards for flavor and texture ${ }^{257,258}$, and new gene-edited crops could conceivably meet these criteria. The benefits of PLW reductions from gene editing may not be realized as quickly as in Europe.

\section{Conclusion}

Gene manipulation alone cannot solve the problem of horticultural loss and waste, as the overall issue remains heterogeneous and multi-faceted, requiring transdisciplinary advances, and the integration of biological, engineering, and socio-cultural solutions. Consumer awareness campaigns about saving produce are notoriously difficult to develop and implement, and success is variable because human behavior is often intractable. Realizing engineering solutions requires massive longterm investments in infrastructure, equipment, and energy. It is against this backdrop that we explored the potential of gene editing for improving produce to be hardier in the supply chain as well as meet consumer expectations.

Manipulating biological processes by gene editing is both a promising new avenue for reducing PLW and a major challenge that relies on understanding the baroque regulation of these pathways in order to "tweak" them in a

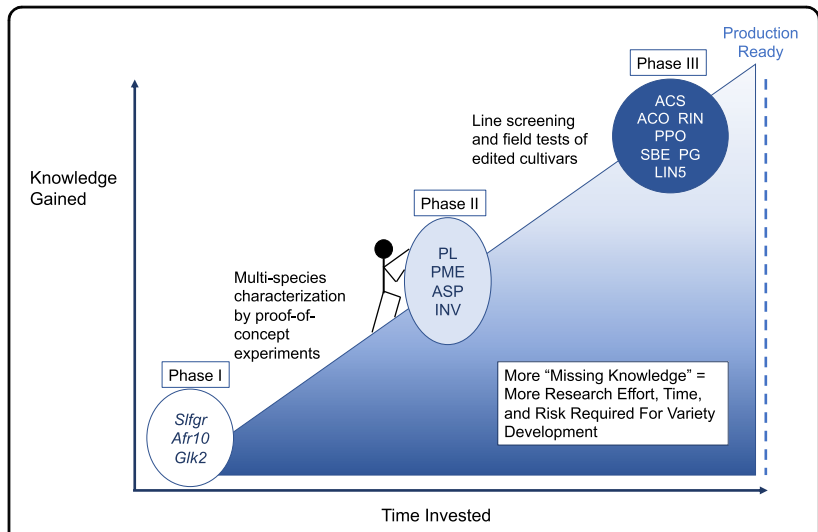

Fig. 7 Gene targets for commercialization of novel gene-edited crops. Genes listed in the dark blue oval to the right have been well studied and are likely to have commercially relevant phenotypes, while those in white still require additional testing because the action of these genes have only been demonstrated in a single species. Phase I: Afr10-higher fruit sugars; Glk2-higher tomato sugars and flavonoids; Slfgr-sweeter tomato fruit. Phase II: INV, ASP reduced cold-induced sweetening and acrylamide produced during processing in potato; $P M E_{;} P L$-reduced fruit softening, better storability and consumer acceptance. Phase III: ACS, ACO, RINreduced rate of ripening; $P G$-reduced fruit softening would cause less bruising during shipment, $P P O$-non-browning, better consumer appeal if bruised postharvest; LIN5-higher accumulation of sugars in fruit; SBE-higher fiber potato for health

beneficial way (Figs. 2,3, and 4). Because the technique is relatively cheap and easy, with minimal impact on the genome (Fig. 6), the cost barrier is such that for the first time, breeders can feasibly engineer postharvest traits with the expectation that the new germplasm could be commercially viable. This means that in spite of the challenges we have outlined (Figs. 5 and 6), there is reason to believe widespread gene editing for PLW reduction is possible and imminent.

As shown in Fig. 7, several genes have been proven to provide reliable phenotypes for reducing PLW, and there are others that are very promising. Many projects are underway to recapitulate these findings using gene-editing approaches, for extended shelf-life or better quality in major commercial species ${ }^{85,99,198,201,259,260}$. Stacking edited alleles of these genes in crops may also lead to additive or valuable transgressive effects. It is our opinion that gene-edited crops will eventually be in broad use across the globe, because of the clear evidence of their potential to minimize postharvest waste and loss in the context of multiple threats to the stability of the world produce supply chain.

\section{Acknowledgements}

E.N.S.'s Ph.D. is supported by a National Science Foundation Graduate Research Fellowship; J.Y.'s Master's degree is supported by the Paulden F. \& Dorathea Knowles Scholarship, and a UC Davis Horticulture \& Agronomy Graduate Group Scholarship; J.Z. thanks the China Scholarship Council, and the UC Davis 
Horticulture \& Agronomy Graduate Group Scholarship for her Master's funding. E.N.S., J.Y., and J.Z. thank the Henry A. Jastro Graduate Research Award for research support. K.A. thanks the Departamento de Producción Vegetal at the Universidad de Concepción for grant support; funding for gene-editing research in DB's lab is provided by USDA Hatch Project CA-D-PLS-2404-H. We thank the UC Davis Postharvest Technology Center, Drs. Elizabeth Maynard, Gerald Brust, Richard Smith, and Marita Cantwell for permission to reuse images. We apologize to those authors whose work we did not cite because of space constraints.

\section{Author details}

'Department of Plant Sciences, University of California, Davis, CA 95616, USA. ${ }^{2}$ Plant Biology Graduate Group, University of California, Davis, CA 95616, USA. ${ }^{3}$ Graduate Group of Horticulture \& Agronomy, University of California, Davis, CA 95616, USA. ${ }^{4}$ Departamento de Produccion Vegetal, Universidad de Concepcion, Region del BioBio, Concepcion, Chile

\section{Conflict of interest}

The authors declare that they have no conflict of interest.

Received: 23 July 2020 Revised: 19 October 2020 Accepted: 22 October 2020

Published online: 01 January 2021

\section{References}

1. Wolter, F., Schindele, P. \& Puchta, H. Plant breeding at the speed of light: the power of CRISPR/Cas to generate directed genetic diversity at multiple sites. BMC Plant Biol. 19, 176 (2019).

2. Pradhan, P., Fischer, G., van Velthuizen, H., Reusser, D. E. \& Kropp, J. P. Closing yield gaps: how sustainable can we be? PLOS ONE 10, e0129487 (2015).

3. Alfa, H. H. \& Arroo, R. R. J. Over 3 decades of research on dietary flavonoid antioxidants and cancer prevention: What have we achieved? Phytochem Rev. 18, 989-1004 (2019).

4. Fraga, C. G., Croft, K. D., Kennedy, D. O. \& Tomas-Barberan, F. A. The effects of polyphenols and other bioactives on human health. Food Funct. 10, 514-528 (2019).

5. Liskova, A. et al. Dietary phytochemicals targeting cancer stem cells. Molecules 24, 899 (2019).

6. Saiwal, N., Dahiya, M. \& Dureja, H. Nutraceutical insight into Vegetables and their Potential for Nutrition Mediated Healthcare. Curr. Nutr. Food Sci. 15 441-453 (2019).

7. FAO. Global Food Losses and Food Waste - Extent, Causes and Prevention. http://www.fao.org/docrep/014/mb060e/mb060e00.pdf (FAO, 2011).

8. Porat, R., Lichter, A., Terry, L. A., Harker, R. \& Buzby, J. Postharvest losses of fruit and vegetables during retail and in consumers' homes: quantifications, causes, and means of prevention. Postharvest Biol. Tec. 139, 135-149 (2018).

9. Kitinoja, L., Tokala, V. V. \& Brondy, A. A review of global postharvest loss assessments in plant-based food crops: recent findings and measurement gaps. J. Postharvest Technol. 6, 1-15 (2018).

10. Bahadur, K. C. K. et al. When too much isn't enough: does current food production meet global nutritional needs? PLOS ONE 13, e0205683 (2018).

11. HPLE. Food Losses and Waste in the Context of Sustainable Food Systems: A Report. http://www.fao.org/3/a-i3901e.pdf (2014).

12. Kader, A. A. Increasing food availability by reducing postharvest losses of fresh produce. In Proc. 5th International Postharvest Symposium, Vols 1-3 2169-2175 (2005).

13. NASEM (ed). in Reducing Impacts of Food Loss and Waste: Proceedings of a Workshop (Committee on Reducing Food Loss and Waste: A Workshop on Impacts; Science and Technology for Sustainability Program; Policy and Global Affairs. National Academies of Sciences, Engineering, and Medicine, 2019).

14. ReFED. A Roadmap to Reduce U.S. Food Waste by 20 Percent (ReFED, 2016).

15. Kader, A. A. in Postharvest Technology of Horticultural Crops Vol. Publication 3529 (ed Kader, A. A.) 39-48 (University of California Agriculture and Natural, 2011).

16. Hewett, E. W. Postharvest Innovation: Current Trends and Future Challenges in the Global Market. In Southeast Asia Symposium on Quality Management in
Postharvest Systems and Asia Pacific Symposium on Postharvest Quality Management of Root and Tuber Crops Vol. 989, 25-37 (2013).

17. Hewett, E. W. Postharvest research for quality horticultural products. Middle East Hortic. Summit 1051, 63-70 (2014).

18. Kader, A. A. \& Saltveit, M. E. Postharvest Physiology and Pathology of Vegetables (eds Bartz, J. A. \& Brecht, J. K.) (CRC Press, 2002).

19. Kays, S. J. Quality maintenance of fresh produce. Acta Hortic. 875, 27-31 (2010).

20. Saltveit, M. E. \& Morris, L. L. Chilling Injury of Horticultural Crops (ed Wang, C. Y.) 3-15 (CRC Press, 1990).

21. Bower, J. H., Blasi, W. V. \& Mitcham, E. J. Effect of ethylene in the storage environment on quality of 'Bartlett pears'. Postharvest Biol. Tec. 28, 371-379 (2003).

22. El-Kereamy, A. et al. Exogenous ethylene stimulates the long-term expression of genes related to anthocyanin biosynthesis in grape berries. Physiol. Plant. 119, 175-182 (2003).

23. Gong, Y. P., Fan, X. T. \& Mattheis, J. P. Responses of 'Bing' and 'Rainier' sweet cherries to ethylene and 1-methylcyclopropene. J. Am. Soc. Hortic. Sci. 127, 831-835 (2002).

24. Friedman, H. in Plant Breeding Reviews (ed Goldman, I.) Ch 3, 61-94 (Wiley, 2020).

25. Liu, Z. Y. \& Jiang, W. B. Lignin deposition and effect of postharvest treatment on lignification of green asparagus (Asparagus officinalis L.). Plant Growth Regul. 48, 187-193 (2006).

26. Ritenour, M. A., Ahrens, M. J. \& Saltveit, M. E. Effects of temperature on ethylene-induced phenylalanine ammonia-lyase activity and russet spotting in harvested iceberg lettuce. J. Am. Soc. Hortic. Sci. 120, 84-87 (1995).

27. Chalutz, E., Devay, J. E. \& Maxie, E. C. Ethylene-induced isocoumarin formation in carrot root tissue. Plant Physiol. 44, 235 (1969).

28. Albornoz, K., Cantwell, M. I., Zhang, L. \& Beckles, D. M. Integrative analysis of postharvest chilling injury in cherry tomato fruit reveals contrapuntal spatiotemporal responses to ripening and cold stress. Sci. Rep. 9, 2795 (2019).

29. Jasin, M. Genetic manipulation of genomes with rare-cutting endonucleases. Trends Genet. 12, 224-228 (1996).

30. Carroll, D. Genome engineering with zinc-finger nucleases. Genetics $\mathbf{1 8 8}$ 773-782 (2011).

31. Hsu, P. D., Lander, E. S. \& Zhang, F. Development and applications of CRISPRCas9 for genome engineering. Cell 157, 1262-1278 (2014).

32. Satheesh, V., Zhang, H., Wang, X. T. \& Lei, M. G. Precise editing of plant genomes - prospects and challenges. Semin. Cell Dev. Biol. 96, 115-123 (2019).

33. Pandey, P. K. et al. Versatile and multifaceted CRISPR/Cas gene editing tool for plant research. Semin. Cell Dev. Biol. 96, 107-114 (2019).

34. Enciso-Rodriguez, F. et al. Overcoming self-incompatibility in diploid potato using CRISPR-Cas9. Front. Plant Sci. 10, 376 (2019).

35. Nadakuduti, S. S., Buell, C. R., Voytas, D. F., Starker, C. G. \& Douches, D. S. Genome editing for crop improvement - applications in clonally propagated polyploids with a focus on potato (Solanum tuberosum L.). Front. Plant Sci. $\mathbf{9}$, 1607 (2018).

36. Sharma, S., Kaur, R. \& Singh, A. Recent advances in CRISPR/Cas mediated genome editing for crop improvement. Plant Biotechnol. Rep. 11, 193-207 (2017).

37. Jinek, $M$. et al. A programmable dual-RNA-guided DNA endonuclease in adaptive bacterial immunity. Science 337, 816-821 (2012).

38. Chen, K. L., Wang, Y. P., Zhang, R., Zhang, H. W. \& Gao, C. X. CRISPR/Cas genome editing and precision plant breeding in agriculture. Annu. Rev. Plant Biol. 70, 667-697 (2019).

39. Metje-Sprink, J., Menz, J., Modrzejewski, D. \& Sprink, T. DNA-free genome editing: past, present and future. Front. Plant Sci. 9, 1957 (2019).

40. Puchta, $\mathrm{H}$. The repair of double-strand breaks in plants: mechanisms and consequences for genome evolution. J. Exp. Bot. 56, 1-14 (2005).

41. Rees, H. A. \& Liu, D. R. Base editing: precision chemistry on the genome and transcriptome of living cells (vol 19, pg 770, 2018). Nat. Rev. Genet. 19, 801-801 (2018).

42. Shimatani, Z. et al. Targeted base editing in rice and tomato using a CRISPRCas9 cytidine deaminase fusion. Nat. Biotechnol. 35, 441 (2017).

43. Zong, Y. et al. Precise base editing in rice, wheat and maize with a Cas9cytidine deaminase fusion. Nat. Biotechnol. 35, 438 (2017).

44. Veillet, F. et al. The Solanum tuberosum GBSSI gene: a target for assessing gene and base editing in tetraploid potato. Plant Cell Rep. 38, 1065-1080 (2019). 
45. Veillet, F. et al. Transgene-free genome editing in tomato and potato plants using Agrobacterium-mediated delivery of a CRISPR/Cas9 cytidine base editor. Int. J. Mol. Sci. 20, 402 (2019).

46. Decaestecker, W. et al. CRISPR-TSKO: a technique for efficient mutagenesis in specific cell types, tissues, or organs in Arabidopsis. Plant Cell 31, 2868-2887 (2019).

47. Brand, L. et al. A versatile and reliable two-component system for tissuespecific gene induction in Arabidopsis. Plant Physiol. 141, 1194-1204 (2006).

48. Wang, X. et al. An inducible genome editing system for plants. Nat. Plants $\mathbf{6}$, 766-772 (2020).

49. Zhang, H. W. et al. Genome editing of upstream open reading frames enables translational control in plants. Nat. Biotechnol. 36, 894 (2018).

50. Li, T. D. et al. Domestication of wild tomato is accelerated by genome editing. Nat. Biotechnol. 36, 1160 (2018).

51. Zsogon, A. et al. De novo domestication of wild tomato using genome editing. Nat. Biotechnol. 36, 1211 (2018).

52. Cheng, J. F. et al. Downregulation of RdDM during strawberry fruit ripening Genome Biol. 19, 212 (2018).

53. Gao, Y. et al. Diversity and redundancy of the ripening regulatory networks revealed by the fruitENCODE and the new CRISPR/Cas9 CNR and NOR mutants. Hortic. Res. 6, 39 (2019).

54. Huang, $H$. et al. Global increase in DNA methylation during orange fruit development and ripening. Proc. Natl Acad. Sci. USA 116, 1430-1436 (2019).

55. Papikian, A., Liu, W. L., Gallego-Bartolome, J. \& Jacobsen, S. E. Site-specific manipulation of Arabidopsis loci using CRISPR-Cas9 SunTag systems. Nat. Commun. 10, 729 (2019).

56. Wang, W. et al. Transgenerational CRISPR-Cas9 activity facilitates multiplex gene editing in allopolyploid wheat. Crispr J. 1, 65-74 (2018).

57. Schaeffer, S. M. \& Nakata, P. A. CRISPR/Cas9-mediated genome editing and gene replacement in plants: transitioning from lab to field. Plant Sci. 240 130-142 (2015).

58. Eshed, Y. \& Lippman, Z. B. Revolutions in agriculture chart a course for targeted breeding of old and new crops. Science 366, 705 (2019).

59. Hamant, O. Plant scientists can't ignore Jevons paradox anymore. Nat. Plants 6. 720-722 (2020)

60. Haynes-Maslow, L., Parsons, S. E., Wheeler, S. B. \& Leone, L. A. A qualitative study of perceived barriers to fruit and vegetable consumption among lowincome populations, North Carolina, 2011. Prev Chronic Dis. 10, E34 (2013).

61. Lucan, S. C., Barg, F. K. \& Long, J. A. Promoters and barriers to fruit, vegetable, and fast-food consumption among urban, low-income african americans-a qualitative approach. Am. J. Public Health 100, 631-635 (2010).

62. Miller, V. et al. Availability, affordability, and consumption of fruits and vegetables in 18 countries across income levels: findings from the Prospective Urban Rural Epidemiology (PURE) study. Lancet Glob. Health $\mathbf{4}$ E695-E703 (2016).

63. Mook, K., Laraia, B. A., Oddo, V. M. \& Jones-Smith, J. C. Food security status and barriers to fruit and vegetable consumption in two economically deprived communities of Oakland, California, 2013-2014. Prev. Chronic Dis. 13 150402 (2016).

64. Tallant, A., Rettig, M. \& Tennyson, S. Barriers and facilitators for fruit and vegetable consumption among adults in rural counties. Fam. Consum. Sci. Res. J. 47, 87-100 (2018).

65. Possingham, J. V. Fruit and vegetable quality in 21st century-the influence of Japan. J. Jpn Soc. Hortic. Sci. 67, 1250-1254 (1998).

66. Florkowski, W. J. et al. in Postharvest Handling 3rd edn (eds Florkowski, W. J., Shewfelt, R. L., Brueckner, B. \& Prussia, S. E.) 147-166 (Academic Press, 2014).

67. Kader, A. A. Flavor quality of fruits and vegetables. J. Sci. Food Agr. 88 1863-1868 (2008).

68. Florkowski, W., Shewfelt, R. \& Prussia, S. E. in Postharvest Handling- A Systems Approach (eds Florkowski, W. J., Shewfelt, R. L. \& Prussia, S. E.) 592 (Academic Press, 2014).

69. Beckles, D. M. Factors affecting the postharvest soluble solids and sugar content of tomato (Solanum lycopersicum L.) fruit. Postharvest Biol. Tec. 63 129-140 (2012).

70. Barrett, D. M., Beaulieu, J. C. \& Shewfelt, R. Color, flavor, texture, and nutritional quality of fresh-cut fruits and vegetables: desirable levels, instrumental and sensory measurement, and the effects of processing. Crit. Rev. Food Sci. $\mathbf{5 0}$ 369-389 (2010).

71. Mogren, L. et al. The hurdle approach-a holistic concept for controlling food safety risks associated with pathogenic bacterial contamination of leafy green vegetables. A review. Front. Microbiol. 9, 1965 (2018).
72. Breslin, PaulA. S. An evolutionary perspective on food and human taste. Curr. Biol. 23, R409-R418 (2013).

73. Diehl, D. C. et al. Exploring produce industry attitudes: relationships between postharvest handling, fruit flavor, and consumer purchasing. Horttechnology 23, 642-650 (2013)

74. Hebrok, M. \& Boks, C. Household food waste: drivers and potential intervention points for design. An extensive review. J. Clean. Prod. 151, 380-392 (2017).

75. Jaeger, S. R. et al. Consumers' visual attention to fruit defects and disorders: a case study with apple images. Postharvest Biol. Tec. 116, 36-44 (2016).

76. Hamilton, A. J., Lycett, G. W. \& Grierson, D. Antisense gene that inhibits synthesis of the hormone ethylene in transgenic plants. Nature $\mathbf{3 4 6}$, https:// doi.org/10.1038/346284a0 (1990).

77. López-Gómez, R. et al. Ripening in papaya fruit is altered by ACC oxidase cosuppression. Transgenic Res 18, 89-97 (2009).

78. Nagata, M. et al. Modification of tomato fruit ripening by transformation with sense or antisense chimeric 1-aminocyclopropane-1-carboxylate synthase genes. Acta Hortic. 394, 213-218 (1995).

79. Oeller, P. W., Min-Wong, L., Taylor, L. P., Pike, D. A. \& Theologis, A. Reversible inhibition of tomato fruit senescence by antisense RNA. Science $\mathbf{2 5 4}$, https:/ doi.org/10.1126/science.1925603 (1991).

80. Xiong, A.-S. et al. Different effects on ACC oxidase gene silencing triggered by RNA interference in transgenic tomato. Plant Cell Rep. 23, 639-646 (2005)

81. Xue, C. et al. Genome wide identification and functional characterization of strawberry pectin methylesterases related to fruit softening. BMC Plant Biol. 20, 13 (2020)

82. Atkinson, R. G. et al. Dissecting the role of climacteric ethylene in kiwifruit (Actinidia chinensis) ripening using a 1-aminocyclopropane-1-carboxylic acid oxidase knockdown line. J. Exp. Bot. 62, 3821-3835 (2011).

83. Ayub, R. et al. Expression of ACC oxidase antisense gene inhibits ripening of cantaloupe melon fruits. Nat. Biotechnol. 14, 862-866 (1996).

84. Lu, P. T. et al. Genome encode analyses reveal the basis of convergent evolution of fleshy fruit ripening. Nat. Plants 4, 784-791 (2018).

85. Yu, Q.-h et al. CRISPR/Cas9-induced targeted mutagenesis and gene replacement to generate long-shelf life tomato lines. Sci. Rep. 7, 11874 (2017).

86. Wang, R. F. et al. Re-evaluation of transcription factor function in tomato fruit development and ripening with CRISPR/Cas9-mutagenesis. Sci. Rep. 9, 1696 (2019).

87. Ito, Y., Nishizawa-Yokoi, A., Endo, M., Mikami, M. \& Toki, S. CRISPR/Cas9mediated mutagenesis of the RIN locus that regulates tomato fruitripening. Biochem. Biophys. Res. Commun. 467, 76-82 (2015).

88. MarketWatch. Floriculture Market 2019 Global Industry Size, Share, Forecasts Analysis, Company Profiles, Competitive Landscape and Key Regions 2024 Available at 360 Research Reports. https:/www.marketwatch.com/pressrelease/floriculture-market-2019-global-industry-size-share-forecasts-analysiscompany-profiles-competitive-landscape-and-key-regions-2024-available-at360-research-reports-2019-09-26 (2019).

89. Xia, Y., Deng, X., Zhou, P., Shima, K. \& Teixeira da Silva, J. A. in Floriculture, Ornamental and Plant Biotechnology - Advances and Topical Issues Vol. 1-4 (ed Teixeira da Silva, J. A.) (Global Science Books, Ltd., 2006).

90. Pranuthi, P., Suseela, T., Swami, D. V., Salomi Suneetha, D. R. \& Sudha Vani, V. Effect of packing and storage conditions on physiological loss in weight, diameter of the flower, electrolyte leakage in extending the vase life of Carnation cv. Kiro. Int. J. Curr. Microbiol. Appl. Sci. 7, 1278-1287 (2018).

91. Mamias, S. The Floriculture Supply Chain: Characteristics And Prospects (Union Fleurs-International Flower Trade Association, The Netherlands, 2018).

92. Fredenburgh, F. The 4,000 mile flower delivery. http://wnw.bbc.com/future/ bespoke/made-on-earth/the-new-roots-of-the-flower-trade/ (2019).

93. Savin, K. W. et al. Antisense Acc oxidase RNA delays carnation petal senescence. Hortscience 30, 970-972 (1995).

94. Woodson, W. R., Park, K. Y., Drory, A., Larsen, P. B. \& Wang, H. Expression of ethylene biosynthetic-pathway transcripts in senescing carnation flowers. Plant Physiol. 99, 526-532 (1992).

95. Wu, M. J., Vandoorn, W. G. \& Reid, M. S. Variation in the senescence of carnation (Dianthus-Caryophyllus L) Cultivars .1. Comparison of flower life, respiration and ethylene biosynthesis. Sci. Hortic. 48, 99-107 (1991).

96. Chang, X. X. et al. A petunia homeodomain-leucine zipper protein, PhHDZip, plays an important role in flower senescence. PLoS ONE 9, e88320 (2014).

97. Tan, Y. Y. et al. PhGRL2 protein, interacting with PhACO1, is involved in flower senescence in the petunia. Mol. Plant. 7, 1384-1387 (2014). 
98. Wang, $H$. et al. Transcriptome changes associated with delayed flower senescence on transgenic petunia by inducing expression of etr1-1, a mutant ethylene receptor. PLOS ONE 8, e65800 (2013).

99. Xu, J. et al. CRISPR/Cas9-mediated editing of 1-aminocyclopropane-1carboxylate oxidase1 enhances Petunia flower longevity. Plant Biotechnol. J. 18, 287-297 (2020)

100. Reid, M. S. \& Jiang, C.-Z. in Horticultural Reviews Vol. 40 (ed. Janick, J.) 1-44 (John Wiley \& Sons, Inc., 2012).

101. Lara, I., Belge, B. \& Goulao, L. F. The fruit cuticle as a modulator of postharvest quality. Postharvest Biol. Technol. 87, 103-112 (2014).

102. Lara, I., Heredia, A. \& Dominguez, E. Shelf life potential and the fruit cuticle: the unexpected player. Front. Plant Sci. 10, 770 (2019)

103. Benichou, M. et al. in Postharvest Biology and Technology of Temperate Fruits (eds Mir, S. A., Shah, M. A. \& Mir, M. M.) 77-100 (Spring International Publishing, 2018).

104. Petit, J., Bres, C., Mauxion, J. P., Bakan, B. \& Rothan, C. Breeding for cuticleassociated traits in crop species: traits, targets, and strategies. J. Exp. Bot. 68 5369-5387 (2017).

105. Rid, M., Markheiser, A., Hoffmann, C. \& Gross, J. Waxy bloom on grape berry surface is one important factor for oviposition of European grapevine moths. J. Pest Sci. 91, 1225-1239 (2018)

106. Loypimai, P., Paewboonsom, S., Damerow, L. \& Blanke, M. M. The wax bloom on bluebern: application of luster sensor technology to assess glossiness and the effect of polishing as a fruit quality parameter. J. Appl Bot. Food Qual. 90 154-158 (2017)

107. Storey, R. \& Price, W. E. Microstructure of the skin of d'Agen plums. Sci. Hortic 81, 279-286 (1999)

108. Trivedi, P. et al. Developmental and environmental regulation of cuticular wax biosynthesis in fleshy fruits. Front. Plant Sci 10, 431 (2019).

109. Bruggenwirth, M. \& Knoche, M. Cell wall swelling, fracture mode, and the mechanical properties of cherry fruit skins are closely related. Planta $\mathbf{2 4 5}$ 765-777 (2017).

110. Knoche, M. \& Grimm, E. Surface moisture induces microcracks in the cuticle of 'Golden Delicious' apple. Hortscience 43, 1929-1931 (2008).

111. Dominguez, E. et al. Tomato fruit continues growing while ripening, affecting cuticle properties and cracking. Physiol. Plant. 146, 473-486 (2012)

112. Giovannoni, J. Molecular biology of fruit maturation and ripening. Annu Rev. Plant Phys. 52, 725-749 (2001).

113. Cantu, D. et al. Ripening-regulated susceptibility of tomato fruit to Botrytis cinerea requires NOR but not RIN or ethylene. Plant Physiol. 150, 1434-1449 (2009).

114. Payasi, A., Mishra, N. N., Chaves, A. L. S. \& Singh, R. Biochemistry of fruit softening: an overview. Physiol. Mol. Biol. Plants 15, 103-113 (2009).

115. Posé, S. et al. Insights into the effects of polygalacturonase FaPG1 gene silencing on pectin matrix disassembly, enhanced tissue integrity, and firmness in ripe strawberry fruits. J. Exp. Bot. 64 3803-3815 (2013).

116. Brummell, D. A. \& Harpster, M. H. Cell wall metabolism in fruit softening and quality and its manipulation in transgenic plants. Plant Mol. Biol. 47, 311-340 (2001).

117. Jiménez-Bermudez, S. et al. Manipulation of strawberry fruit softening by antisense expression of a pectate lyase gene. Plant Physiol. 128, 751-759 (2002)

118. Santiago-Domenech, N. et al. Antisense inhibition of a pectate lyase gene supports a role for pectin depolymerization in strawberry fruit softening. $J$. Exp. Bot. 59, 2769-2779 (2008)

119. Yang, L. et al. Silencing of SIPL, which encodes a pectate lyase in tomato, confers enhanced fruit firmness, prolonged shelf-life and reduced susceptibility to grey mould. Plant Biotechnol. J. 15, 1544-1555 (2017).

120. Tieman, D. M., Harriman, R. W., Ramamohan, G. \& Handa, A. K. An antisense pectin methylesterase gene alters pectin chemistry and soluble solids in tomato fruit. Plant Cell. 4, 667-679 (1992).

121. Wang, S. Y., Zhou, Q., Zhou, X., Zhang, F. \& Ji, S. J. Ethylene plays an important role in the softening and sucrose metabolism of blueberries postharvest. Food Chem. 310, 125965 (2020).

122. Wen, B., Strom, A., Tasker, A., West, G. \& Tucker, G. A. Effect of silencing the two major tomato fruit pectin methylesterase isoforms on cell wall pectin metabolism. Plant Biol. 15, 1025-1032 (2013).

123. Smith, D. L., Abbott, J. A. \& Gross, K. C. Down-regulation of tomato betagalactosidase 4 results in decreased fruit softening. Plant Physiol. 129, 1755-1762 (2002).
124. Moctezuma, E., Smith, D. L. \& Gross, K. C. Antisense suppression of a betagalactosidase gene (TBG6) in tomato increases fruit cracking. J. Exp. Bot. $\mathbf{5 4}$ 2025-2033 (2003).

125. Carey, A. T. et al. Down-regulation of a ripening-related beta-galactosidase gene (TBG1) in transgenic tomato fruits. J. Exp. Bot. 52, 663-668 (2001).

126. Uluisik, S. et al. Genetic improvement of tomato by targeted control of fruit softening. Nat. Biotechnol. 34, 950 (2016).

127. Smith, C. J. S. et al. Inheritance and effect on ripening of antisense polygalacturonase genes in transgenic tomatoes. Plant Mol. Biol. 14, 369-379 (1990).

128. Wormit, A. \& Usadel, B. The multifaceted role of pectin methylesterase inhibitors (PMEls). Int. J. Mol. Sci. 19, 2878 (2018).

129. Encinas-Basurto, D. et al. Alterations in volatile metabolites profile of fresh tomatoes in response to Alternaria alternata (Fr.) Keissl. 1912 infection. Chil. J. Agr. Res. 77, 194-201 (2017).

130. Peris, J. E., Rodriguez, A., Pena, L. \& Fedriani, J. M. Fungal infestation boosts fruit aroma and fruit removal by mammals and birds. Sci. Rep. 7, 5646 (2017).

131. Rodrigo, J. E. P., Laffitte, J. M. F. \& García, L. P. Los mamíferos frugívoros prefieren frutos de cítricos infectados por Penicillium:i se equivocaba Janzen? Rev. Ecosistemas 24, 5-13 (2015).

132. Rodriguez, A., Alquezar, B. \& Pena, L. Fruit aromas in mature fleshy fruits as signals of readiness for predation and seed dispersal. N. Phytol. 197, 36-48 (2013).

133. Vilanova, L. et al. Differential contribution of the two major polygalacturonases from Penicillium digitatum to virulence towards citrus fruit. Int J. Food Microbiol. 282, 16-23 (2018).

134. Silva, C. J. et al. Tomato fruit susceptibility to fungal disease can be uncoupled from ripening by suppressing susceptibility factors. Preprint at https://www. biorxiv.org/content/10.1101/2020.06.03.132829v1.full (2020).

135. Porat, R., McCollum, T. G., Vinokur, V. \& Droby, S. Effects of various elicitors on the transcription of a beta-1,3-endoglucanase gene in citrus fruit. J. Phytopathol. 150, 70-75 (2002)

136. Distefano, G. et al. Defence-related gene expression in transgenic lemon plants producing an antimicrobial Trichoderma harzianum endochitinase during fungal infection. Transgenic Res. 17, 873-879 (2008).

137. Muccilli, V. et al. Substantial equivalence of a transgenic lemon fruit showing postharvest fungal pathogens resistance. J. Agr. Food Chem. 68, 3806-3816 (2020).

138. Ballester, A. R. et al. Transcriptomic profiling of citrus fruit peel tissues reveals fundamental effects of phenylpropanoids and ethylene on induced resistance. Mol. Plant Pathol. 12, 879-897 (2011).

139. Gonzalez-Candelas, L., Alamar, S., Sanchez-Torres, P., Zacarias, L. \& Marcos, J. F. A transcriptomic approach highlights induction of secondary metabolism in citrus fruit in response to Penicillium digitatum infection. BMC Plant Biol. 10, 194 (2010).

140. Chen, J. Y., Shen, Y. T., Chen, C. Y. \& Wan, C. P. Inhibition of key citrus postharvest fungal strains by plant extracts in vitro and in vivo: a review. Plants 8, 26 (2019).

141. Sanzani, S. M., Schena, L. \& Ippolito, A. Effectiveness of phenolic compounds against citrus green mould. Molecules 19, 12500-12508 (2014).

142. Khoo, H. E., Azlan, A., Kong, K. \& Ismail, A. Phytochemicals and medicinal properties of indigenous tropical fruits with potential for commercial development. Evid. Based Compl. Alt. 2016, 7591951 (2016).

143. Zhang, Y. et al. Anthocyanins double the shelf life of tomatoes by delaying overripening and reducing susceptibility to gray mold. Curr. Biol. 23, 1094-1100 (2013).

144. Zhang, Y. et al. Different reactive oxygen species scavenging properties of flavonoids determine their abilities to extend the shelf life of tomato. Plant Physiol. 169, 1568-1583 (2015).

145. Bassolino, L. et al. Accumulation of anthocyanins in tomato skin extends shelf life. N. Phytol. 200, 650-655 (2013).

146. Mes, P. J., Boches, P., Myers, J. R. \& Durst, R. Characterization of tomatoes expressing anthocyanin in the fruit. J. Am. Soc. Hortic. Sci. 133, 262-269 (2008).

147. Nookaraju, A. et al. Molecular approaches for enhancing sweetness in fruits and vegetables. Sci. Hortic. 127, 1-15 (2010).

148. Beckles, D. M., Hong, N., Stamova, L. \& Luengwilai, K. Biochemical factors contributing to tomato fruit sugar content: a review. Fruits 67, 49-64 (2012).

149. Beauvoit, B. et al. Putting primary metabolism into perspective to obtain better fruits. Ann. Bot. 122, 1-21 (2018). 
150. Fridman, E., Carrari, F., Liu, Y. S., Fernie, A. R. \& Zamir, D. Zooming in on a quantitative trait for tomato yield using interspecific introgressions. Science 305, 1786-1789 (2004).

151. Petreikov, M. et al. Carbohydrate balance and accumulation during development of near-isogenic tomato lines differing in the AGPase-L1 allele. J. Am. Soc. Hortic. Sci. 134, 134-140 (2009).

152. Centeno, D. C. et al. Malate plays a crucial role in starch metabolism, ripening, and soluble solid content of tomato fruit and affects postharvest softening. Plant Cell. 23, 162-184 (2011).

153. Powell, A. L. T. et al. Uniform ripening encodes a golden 2-like transcription factor regulating tomato fruit chloroplast development. Science 336 1711-1715 (2012).

154. Sagar, M. et al. SIARF4, an auxin response factor involved in the control of sugar metabolism during tomato fruit development. Plant Physiol. 161, 1362-1374 (2013).

155. Sagor, G. H. M. et al. A novel strategy to produce sweeter tomato fruits with high sugar contents by fruit-specific expression of a single bZIP transcription factor gene. Plant Biotechnol. J. 14, 1116-1126 (2016).

156. Shammai, A. et al. Natural genetic variation for expression of a SWEET transporter among wild species of Solanum lycopersicum (tomato) determines the hexose composition of ripening tomato fruit. Plant J. 96, 343-357 (2018).

157. Yuan, Y. et al. (2018). SIARF10, an auxin response factor, is involved in chlorophyll and sugaraccumulation during tomato fruit development. J. Exp. Bot. 69, 5507-5518 (2018).

158. Cheng, J. T. et al. Overexpression of the tonoplast sugar transporter CmTST2 in melon fruit increases sugar accumulation. J. Exp. Bot. 69, 511-523 (2018).

159. Smith, A. M., Denyer, K. \& Martin, C. R. What controls the amount and structure of starch in storage organs. Plant Physiol. 107, 673-677 (1995).

160. Andersson, M. et al. Efficient targeted multiallelic mutagenesis in tetraploid potato (Solanum tuberosum) by transient CRISPR-Cas9 expression in protoplasts. Plant Cell Rep. 36, 117-128 (2017).

161. Beckles, D. M. \& Thitisaksakul, M. in Encyclopedia of Biotechnology in Agriculture and Food (eds Heldman, D., Hoover, D. \& Wheeler, M.) 8 (CRC Press, Boca Raton, 2014).

162. Wang, H. X. et al. CRISPR/Cas9-based mutagenesis of starch biosynthetic genes in sweet potato (Ipomoea Batatas) for the improvement of starch quality. Int. J. Mol. Sci. 20, 4702 (2019).

163. Li, H. T., Gidley, M. J. \& Dhital, S. High-amylose starches to bridge the "fiber gap": development, structure, and nutritional functionality. Compr. Rev. Food Sci. Food Saf. 18, 362-379 (2019).

164. Jobling, S. Improving starch for food and industrial applications. Curr. Opin. Plant Biol. 7, 210-218 (2004).

165. Hofvander, P., Andersson, M., Larsson, C. T. \& Larsson, H. Field performance and starch characteristics of high-amylose potatoes obtained by antisense gene targeting of two branching enzymes. Plant Biotechnol. J. 2, 311-320 (2004).

166. Jobling, S. A., Westcott, R. J., Tayal, A., Jeffcoat, R. \& Schwall, G. P. Production of a freeze-thaw-stable potato starch by antisense inhibition of three starch synthase genes. Nat. Biotechnol. 20, 295-299 (2002).

167. Schwall, G. P. et al. Production of very-high-amylose potato starch by inhibition of SBE A and B. Nat. Biotechnol. 18, 551-554 (2000).

168. Visser, R. G. F. et al. Inhibition of the expression of the gene for granulebound starch synthase in potato by antisense constructs. Mol. Gen. Genet. 225, 289-296 (1991).

169. Dong, S. Y. \& Beckles, D. M. Dynamic changes in the starch-sugar interconversion within plant source and sink tissues promote a better abiotic stress response. J. Plant Physiol. 234, 80-93 (2019)

170. Luengwilai, K. \& Beckles, D. M. Starch granules in tomato fruit show a complex pattern of degradation. J. Agric. Food Chem. 57, 8480-8487 (2009).

171. McKibbin, R. S. et al. Production of high-starch, low-glucose potatoes through over-expression of the metabolic regulator SnRK1. Plant Biotechnol. J. 4, 409-418 (2006).

172. Regierer, B. et al. Starch content and yield increase as a result of altering adenylate pools in transgenic plants. Nat. Biotechnol. 20, 1256-1260 (2002).

173. Burton, W. G. The sugar balance in some British potato varieties during storage. II. The effects of tuber age, previous storage temperature, and intermittent refrigeration upon low-temperature sweetening. Eur. Potato $\mathrm{J}$. 12, 81-95 (1969)
174. Amir, J., Kahn, V. \& Unterman, M. Respiration, Atp level, and sugar accumulation in potato-tubers during storage at 4-degrees. Phytochemistry $\mathbf{1 6}$ 1495-1498 (1977).

175. Mottram, D. S., Wedzicha, B. L. \& Dodson, A. T. Acrylamide is formed in the Maillard reaction. Nature 419, 448-449 (2002).

176. Gokmen, V. \& Palazoglu, T. K. Acrylamide formation in foods during thermal processing with a focus on frying. Food Bioprocess Technol. 1, 35-42 (2008).

177. Morrell, S. \& Aprees, T. Control of the hexose content of potato-tubers. Phytochemistry 25, 1073-1076 (1986).

178. Lorberth, R., Ritte, G., Willmitzer, L. \& Kossmann, J. Inhibition of a starchgranule-bound protein leads to modified starch and repression of cold sweetening. Nat. Biotechnol. 16, 473-477 (1998).

179. Cochrane, M. P., Duffus, C. M., Allison, M. J. \& Mackay, G. R. Amylolytic activity in stored potato-tubers .2. The effect of low-temperature storage on the activities of alpha-amylase and beta-amylase and alpha-glucosidase in potato-tubers. Potato Res. 34, 333-341 (1991).

180. Claassen, P. A. M., Budde, M. A. W. \& Vancalker, M. H. Increase in phosphorylase-activity during cold-induced sugar accumulation in potatotubers. Potato Res. 36, 205-217 (1993).

181. Zrenner, R., Schuler, K. \& Sonnewald, U. Soluble acid invertase determines the hexose-to-sucrose ratio in cold-stored potato tubers. Planta 198, 246-252 (1996).

182. Yu, X. Y. et al. Antisense suppression of an acid invertase gene (MAl1) in muskmelon alters plant growth and fruit development. J. Exp. Bot. 59, 2969-2977 (2008).

183. Cheng, M., Lowe, B. A., Spencer, T. M., Ye, X. D. \& Armstrong, C. L. Factors influencing Agrobacterium-mediated transformation of monocotyledonous species. Vitr. Cell Dev. 40, 31-45 (2004).

184. Bhaskar, P. B. et al. Suppression of the vacuolar invertase gene prevents coldinduced sweetening in potato. Plant Physiol. 154, 939-948 (2010).

185. Richael, C. et al. POTATO CULTIVAR W8. USA patent (2015).

186. Klein, D., Gkisakis, V., Krumbein, A., Livieratos, I. \& Kopke, U. Old and endangered tomato cultivars under organic greenhouse production: effect of harvest time on flavour profile and consumer acceptance. Int J. Food Sci. Technol. 45, 2250-2257 (2010).

187. Causse, M., Buret, M., Robini, K. \& Verschave, P. Inheritance of nutritional and sensory quality traits in fresh market tomato and relation to consumer preferences. J. Food Sci. 68, 2342-2350 (2003).

188. Causse, M. et al. Consumer preferences for fresh tomato at the european scale: a common segmentation on taste and firmness. J. Food Sci. 75, S531-S541 (2010).

189. Sinesio, F. et al. Sensory quality of fresh french and dutch market tomatoes: a preference mapping study with italian consumers. J. Food Sci. 75, S55-S67 (2010).

190. Zhang, B. et al. Chilling-induced tomato flavor loss is associated with altered volatile synthesis and transient changes in DNA methylation. Proc. Natl Acad. Sci. USA 113, 12580-12585 (2016).

191. Klee, H. J. \& Tieman, D. M. The genetics of fruit flavour preferences. Nat. Rev. Genet. 19, 347-356 (2018).

192. Ferrão, L. F. V. et al. Genome-wide association of volatiles reveals candidate loci for blueberry flavor. N. Phytol. 226, 1725-1737 (2020).

193. Tieman, D. et al. The chemical interactions underlying tomato flavor preferences. Curr. Biol. 22, 1035-1039 (2012).

194. Zhao, J. T. et al. Meta-analysis of genome-wide association studies provides insights into genetic control of tomato flavor. Nat. Commun. 10, 1534 (2019).

195. Mathieu, S. et al. Flavour compounds in tomato fruits: identification of loci and potential pathways affecting volatile composition. J. Exp. Bot. 60 , 325-337 (2009).

196. Galili, G., Galili, S., Lewinsohn, E. \& Tadmor, Y. Genetic, molecular, and genomic approaches to improve the value of plant foods and feeds. Crit. Rev. Plant Sci. 21, 167-204 (2002).

197. He, Q. \& Luo, Y. Enzymatic browning and its control in fresh-cut produce Stewart Postharvest Rev. 6, 1-7 (2007).

198. González, M. N. et al. Reduced enzymatic browning in potato tubers by specific editing of a polyphenol oxidase gene via ribonucleoprotein complexes delivery of the CRISPR/Cas9 system. Front Plant Sci. 10, 1649-1649 (2020).

199. Armstrong, J. \& Lane, W. D. Genetically modified reduced-browning fruit producing plant and produce fruit thereof and method of obtaining such. USA patent (2009) 
200. Brooks, J. Consumer feedback: The world is ready for Arctic ${ }^{\circledast}$ apples. Availabe online: https://www.okspecialtyfruits.com/consumer-feedback-theworld-isready-for-arctic-apples/ (accessed on May 30th), (Okanagan Specialty Fruits Inc. Summerland, British Columbia, 2012)

201. Waltz, E. Gene-edited CRISPR mushroom escapes US regulation. Nature 532, 293 (2016).

202. Beckles, D. M. \& Thitisaksakul, M. How environmental stress affects starch composition and functionality in cereal endosperm. Starch 66, 58-71 (2014).

203. Brandi, M. T., Cox, C. E. \& Teplitski, M. Salmonella interactions with plants and their associated microbiota. Phytopathology 103, 316-325 (2013).

204. Machado-Moreira, B., Richards, K., Brennan, F., Abram, F. \& Burgess, C. M. Microbial contamination of fresh produce: what, where, and how? Compr. Rev. Food Sci. Food Saf. 18, 1727-1750 (2019).

205. Haymaker, J. et al. Prevalence of Shiga-toxigenic and atypical enteropathogenic Escherichia coli in untreated surface water and reclaimed water in the Mid-Atlantic U.S. Environ. Res. 172, 630-636 (2019).

206. Olaimat, A. N. \& Holley, R. A. Factors influencing the microbial safety of fresh produce: a review. Food Microbiol. 32, 1-19 (2012).

207. Teplitski, M., Barak, J. D. \& Schneider, K. R. Human enteric pathogens in produce: un-answered ecological questions with direct implications for food safety. Curr. Opin. Biotechnol. 20, 166-171 (2009).

208. Montano, J. et al. Salmonella enterica serovar typhimurium 14028 s genomic regions required for colonization of lettuce leaves. Front. Microbiol. 11, 6 (2020)

209. Jacob, C. \& Melotto, M. Human pathogen colonization of lettuce dependent upon plant genotype and defense response activation. Front. Plant Sci. 10, 1769 (2020).

210. Melotto, M. et al. Breeding crops for enhanced food safety. Front. Plant Sci. 11, https://doi.org/10.3389/fpls.2020.00428 (2020).

211. Albornoz, K. et al. Investigating postharvest chilling injury in tomato (Solanum lycopersicum L.) fruit using magnetic resonance imaging and 5-azacytidine, a hypomethylation agent. Acta Hortic. 1278, https://doi.org/10.17660/ ActaHortic.12020.11278.17635 (2020).

212. Biswas, P., East, A. R., Hewett, E. W. \& Heyes, J. A. in Horticultural Reviews Vol. 44 (ed Jules Janick) (John Wiley \& Sons, 2017).

213. Liu, Y. D. et al. SIGRAS4 mediates a novel regulatory pathway promoting chilling tolerance in tomato. Plant Biotechnol. J. https://doi.org/10.1111/ pbi.13328 (2020)

214. Ferguson, I., Volz, R. \& Woolf, A. Preharvest factors affecting physiological disorders of fruit. Postharvest Biol. Tec. 15, 255-262 (1999).

215. de Freitas, S. T., Jiang, C. Z. \& Mitcham, E. J. Mechanisms involved in calcium deficiency development in tomato fruit in response to gibberellins. J. Plant Growth Regul. 31, 221-234 (2012).

216. Kader, A. A. in Postharvest Techology of Horticulture Crops (ed Kader, A. A.) 279-285 (University of California ANR Natural Resources, 2002).

217. Kader, A. A. in Postharvest Technology of Horticultural Crops (ed Kader, A. A.) 39-48 (University of California, Agriculture and Natural Resources, 2002).

218. Thompson, A. K. Fruit and Vegetable Storage: Hybobaric, Hyperbaric and Controlled Atmosphere. https://doi.org/10.1007/978-3-319-23591-2 (Springer, 2016).

219. Pedreschi, R. \& Lurie, S. Advances and current challenges in understanding postharvest abiotic stresses in perishables. Postharvest Biol. Technol. 107, 77-89 (2015)

220. Altpeter, F. et al. Advancing crop transformation in the era of genome editing. Plant Cell 28, 1510-1520 (2016).

221. Cohen, S. N., Chang, A. C. Y., Boyer, H. W. \& Helling, R. B. Construction of biologically functional bacterial plasmids in-vitro. Proc. Natl Acad. Sci. USA 70, 3240-3244 (1973).

222. Song, G. Q., Prieto, H. \& Orbovic, V. Agrobacterium-mediated transformation of tree fruit crops: methods, progress, and challenges. Front. Plant Sci. 10, 26 (2019).

223. Sanford, J. C. Biolistic Plant Transformation. Physiol. Plant. 79, 206-209 (1990).

224. Fitch, M. M. M. in Biotechnology of Fruit and Nut Crops (ed Litz, R. E.) 173-208 (CABI Publishing, Cambridge, MA, 2005).

225. Oliveira, M. \& Fraser, L. in Biotechnology of Fruit and Nut Crops (ed Litz, R. E.) 2-28 (CABI Publishing, Cambridge, MA, 2005).

226. Fernandez-Pinan, S. et al. Agrobacterium tumefaciens and Agrobacterium rhizogenes-mediated transformation of potato and the promoter activity of a suberin gene by GUS staining. J. Vis. Exp. https://doi.org/10.3791/59119 (2019).
227. Doyle, C. et al. A simple method for spray-on gene editing in planta. Preprint at https:/doi.org/10.1101/805036 (2019).

228. Maher, M. F. et al. Plant gene editing through de novo induction of meristems. Nat. Biotechnol. https://doi.org/10.1038/s41587-019-0337-2 (2019).

229. Debernardi, J. M. et al. A GRF-GIF chimeric protein improves the regeneration efficiency of transgenic plants. Nat. Biotechnol. 38, 1274-1279 (2020).

230. Kong, J. et al. Overexpression of the transcription factor GROWTHREGULATING FACTOR5 improves transformation of dicot and monocot species. Front. Plant Sci. 11, 1389 (2020).

231. Aurand, R. et al. Anatomical and biochemical trait network underlying genetic variations in tomato fruit texture. Euphytica 187, 99-116 (2012).

232. Nunez-Lillo, G. et al. High-density genetic map and QTL analysis of soluble solid content, maturity date, and mealiness in peach using genotyping by sequencing. Sci. Hortic. 257, 108734 (2019).

233. Hayes, R. J., Galeano, C. H., Luo, Y. G., Antonise, R. \& Simko, I. Inheritance of decay of fresh-cut lettuce in a recombinant inbred line population from 'Salinas 88' x 'La Brillante'. J. Am. Soc. Hortic. Sci. 139, 388-398 (2014).

234. Ogundiwin, E. A., Peace, C. P. \& Gradziel, T. M. Molecular genetic dissection of chilling injury in peach fruit. Acta Hortic. 78, 633-638 (2007).

235. Soltys-Kalina, D. et al. Novel candidate genes AuxRP and Hsp90 influence the chip color of potato tubers. Mol. Breed. 35, 224 (2015).

236. da Costa, J. H. P., Rodriguez, G. R., Pratta, G. R., Picardi, L. A. \& Zorzoli, R. QTL detection for fruit shelf life and quality traits across segregating populations of tomato. Sci. Hortic. 156, 47-53 (2013).

237. Howard, N. P. et al. Two QTL characterized for soft scald and soggy breakdown in apple (Malus $\mathrm{x}$ domestica) through pedigree-based analysis of a large population of interconnected families. Tree Genet. Genomes 14, 2 (2018).

238. Ding, Y. D. et al. Network analysis of postharvest senescence process in citrus fruits revealed by transcriptomic and metabolomic profiling. Plant Physiol. 168, 357-U642 (2015).

239. Tang, N., Deng, W., Hu, N., Chen, N. \& Li, Z. G. Metabolite and transcriptomic analysis reveals metabolic and regulatory features associated with Powell orange pulp deterioration during room temperature and cold storage. Postharvest Biol. Technol. 112, 75-86 (2016).

240. Metje-Sprink, J., Sprink, T. \& Hartung, F. Genome-edited plants in the field. Curr. Opin. Biotechnol. 61, 1-6 (2020).

241. Mika, A. Flux and Uncertainty in the CRISPR Patent Landscape (The Scientist, 2017).

242. Terry, M. UC-Berkely renews U.S. patent dispute with the broad institute over CRISPR. https://www.biospace.com/article/crispr-patent-battle-isn-t-quiteover-yet/ (2019).

243. Rizk, C. CRISPR patent fight turns ugly as UC accuses broad researchers of lying about claims. https://www.genomeweb.com/business-news/crisprpatent-fight-turns-ugly-uc-accuses-broad-researchers-lying-about-claims (2019).

244. Akst, J. USPTO restarts CRISPR patent dispute between broad and UC. https:// www.the-scientist.com/news-opinion/uspto-restarts-crispr-patent-disputebetween-broad-and-uc-66050 (2019).

245. Elsevier. CRISPR. https://www.elsevier.com/research-intelligence/campaigns/ crispr (2016).

246. Kocak, D. D. et al. Increasing the specificity of CRISPR systems with engineered RNA secondary structures. Nat. Biotechnol. 37, 657 (2019).

247. Tan, Y. Y. et al. Rationally engineered Staphylococcus aureus Cas9 nucleases with high genome-wide specificity. Proc. Natl Acad. Sci. USA 116, 20969-20976 (2019).

248. Institute, B. For journalists: statement and background on the CRISPR patent process. https://www.broadinstitute.org/crispr/journalists-statement-andbackground-crispr-patent-process (2017).

249. Rozen, I. Removing a major CRISPR licensing roadblock in agriculture. The Broad Institute. https://www.broadinstitute.org/news/removing-major-crisprlicensing-roadblock-agriculture (2017).

250. Ahuja, V. Regulation of emerging gene technologies in India. BMC Proc. 12 14 (2018).

251. Consortium, E. Regulating genome edited organisms as GMOs has negative consequences for agriculture, society and economy. https://www.mpg.de/ 13748566/position-paper-crispr.pdf (2019).

252. Ledford, H. CRISPR conundrum: strict European court ruling leaves foodtesting labs without a plan. Nature 572, https://doi.org/10.1038/d41586-01902162-x (2019). 
253. Weigel, D., Bock, R. \& Coupland, G. Scientists call for modernization of EU gene-editing legislation. https:/www.mpg.de/13761643/scientists-call-formodernization-of-the-european-genetic-engineering-law (2019).

254. Stokstad, E. United States relaxes rules for biotech crops. (Science Magazine, Plants \& Animals Science and Policy, 2020).

255. Callaway, E. CRISPR plants now subject to tough GM laws in European Union. Nature 560, https://doi.org/10.1038/d41586-018-05814-6 (2018).

256. European Parliament. 32001 L0018 (Official Journal of the European Communities, 2001).

257. Priefer, C., Jörissen, J. \& Bräutigam, K.-R. Food waste prevention in Europe - A cause-driven approach to identify the most relevant leverage points for action. Resour. Conserv. Recycling 109, 155-165 (2016).

258. De Laurentiis, V., Corrado, S. \& Sala, S. Quantifying household waste of fresh fruit and vegetables in the EU. Waste Manag. 77, 238-251 (2018).

259. Tuncel, A. et al. Cas9-mediated mutagenesis of potato starch-branching enzymes generates a range of tuber starch phenotypes. Plant Biotechnol. J. 17, 2259-2271 (2019).

260. Wang, D. D. et al. Characterization of CRISPR mutants targeting genes modulating pectin degradation in ripening tomato. Plant Physiol. 179, 544-557 (2019)

261. Behboodian, B., Mohd Ali, Z., Ismail, I. \& Zainal, Z. Postharvest analysis of lowland transgenic tomato fruits harboring hpRNAi-ACO1construct. Sci. World J. 439870. https://doi.org/10.1100/2012/439870 (2012).

262. Kramer, M., Sanders, R., Bolkan, H., Waters, C., Sheeny, R. E. \& Hiatt, W. R. Postharvest evaluation of transgenic tomatoes with reduced levels of polygalacturonase: processing, firmness and disease resistance. Postharvest Biol. Technol. 1, 241-255 (1992).

263. Quesada, M. A. et al. Antisense down-regulation of the FaPG1 gene reveals an unexpected central role for polygalacturonase in strawberry fruit softening. Plant Physiol. 150, 1022-1032 (2009).

264. Elitzur, T. et al. Banana MaMADS transcription factors are necessary for fruit ripening and molecular tools to promote shelf-life and food security. Plant Physiol. 171, 380-391 (2016).

265. Yang, L. et al. Silencing of SI PL, which encodes a pectate lyase in tomato, confers enhanced fruit firmness, prolonged shelf-life and reduced susceptibility to grey mould. Plant Biotechnol. J. 15, 1544-1555 (2017).
266. Tieman, D. M., Harriman, R. W., Ramamohan, G. \& Handa, A. K. An antisense pectin methylesterase gene alters pectin chemistry and soluble solids in tomato fruit. The Plant Cell 4, 667-679 (1992).

267. Ban, $\mathrm{Q}$. et al. Functional characterization of persimmon $\beta$-galactosidase gene DKGAL1 in tomato reveals cell wall modification related to fruit ripening and radicle elongation. Plant Science 274, 109-120 (2018).

268. Paniagua, $C$. et al. Antisense downregulation of the strawbern $\beta$-galactosidase gene FaßGal4 increases cell wall galactose levels and reduces fruit softening. J. Exp. Bot. 67, 619-631 (2016).

269. Fu, D. Q., Zhu, B. Z., Zhu, H. L., Jiang, W. B., \& Luo, Y. B. Virus-induced gene silencing in tomato fruit. Plant J. 43, 299-308 (2005).

270. Huang, L. C. et al. Delayed flower senescence of Petunia hybrida plants transformed with antisense broccoli ACC synthase and ACC oxidase genes. Postharvest Biol. Technol. 46, 47-53 (2007).

271. Rommens, C. M., Ye, J., Richael, C. \& Swords, K. Improving potato storage and processing characteristics through all-native DNA transformation. J. Agric. Food Chem. 54, 9882-9887 (2006).

272. Rommens, C. M., Yan, H., Swords, K., Richael, C., \& Ye, J. (2008). Low-acrylamide French fries and potato chips. Plant Biotechnol. J. 6, 843-853 (2008).

273. van Rijswick, C. World Fruit Map 2018: Global Trade Still Fruitful. RaboResearch Food \& Agribusiness (2018)

274. Houben, M. \& Van de Poel, B. 1-Aminocyclopropane-1-carboxylic acid oxidase (ACO): the enzyme that makes the plant hormone ethylene. Front. Plant Sci. 10, 695 (2019).

275. Yang, S. F. \& Hoffman, N. E. Ethylene biosynthesis and its regulation in higherplants. Annu Rev. Plant Phys. 35, 155-189 (1984).

276. Martinez-Romero, D. et al. Tools to maintain postharvest fruit and vegetable quality through the inhibition of ethylene action: a review. Crit. Rev. Food Sci. 47, 543-560 (2007)

277. Hyde, P. T., Guan, X., Abreu, V. \& Setter, T. L. The anti-ethylene growth regulator silver thiosulfate (STS) increases flower production and longevity in cassava (Manihot esculenta Crantz). Plant Growth Regul. 90, 441-453 (2020).

278. de Wild, H. P. J., Otma, E. C. \& Peppelenbos, H. W. Carbon dioxide action on ethylene biosynthesis of preclimacteric and climacteric pear fruit. J. Exp. Bot. 54, 1537-1544 (2003).

279. Watkins, C. B. The use of 1-methylcyclopropene (1-MCP) on fruits and vegetables. Biotechnol. Adv. 24, 389-409 (2006). 